\title{
Yüzey Araştırmalar Işı̆̆ında Erzurum Pasinler İlçesinde Tespit Edilen Obsidyen Merkezleri ve Atölyeleri
}

\author{
Alpaslan CEYLAN ve Seval AKÇELİK
}

$\ddot{O} z$

Kuzeydoğu Anadolu Bölgesi, jeolojik yapısı nedeniyle önemli obsidyen yataklarına ev sahipliği yapmaktadır. Ana hatlarıyla Erzurum-Kars Platosu'nda bulunan volkanik sahalar, bölgenin temel obsidyen kaynaklarını oluşturmaktadır. Erzurum'un batısında yer alan Söğütlü'nün kuzeyindeki tepelik alanlar, Palandöken Dağı’nın güneybatısı, Pasinler ve çevresi obsidyen yataklarının tespit edildiği önemli arazilerdir. Pasinler ilçesi jeolojik karakterini, Pliosen sonu ve Pleistosen içinde meydana gelen tektonik hareketler sonucunda kazanmıştır. İlçe ve yakın çevresinde andezit, bazalt ve obsidyen gibi dış püskürük kayaçlar geniş bir yayılım göstermektedir. Bölgede 1998 yılında başladığımız yüzey araştırmalarında çalışma sahalarımızdan biri de Pasinler olmuştur. Pasinlerde yaptığımız çalışmalarda çok sayıda keramik ve obsidyen tespit edilmiştir. Gelişmiş obsidyen analiz yöntemlerine rağmen çalışma alanımızda bulunan merkezlerin sadece birkaçından alınan örneklerin analizleri yapılmıştır. İlçe ve yakın çevresinde Kotandüzü, Pelitli ve Tımar gibi önemli obsidyen merkezlerinin yanı sıra Cin Kalesi, Çalıyazı Kalesi, Kavuşturan Kalesi ve Sos Höyük’te yapılan araştırmalarda bu merkezlerin de önemli birer obsidyen atölyesi olabileceği düşünülmektedir. Ayrıca Pasinler'deki obsidyen yatakları ve atölyeleri yakın merkezlerin kısmen ihtiyacını karşılamasının yanı sıra kilometrelerce uzaklıktaki merkezlerle takas ve ticareti yapıldığı analizler neticesinde ortaya konulmuştur.

Anabtar Kelimeler: Erzurum, Pasinler, Obsidyen, Atölye.

Obsidian Centers and Workshops Identified in Erzurum Pasinler District in the Light of Surface Surveys

\begin{abstract}
The Northeastern Anatolian Region is home to important obsidian deposits due to its geological structure. The volcanic fields, mainly located on the Erzurum-Kars Plateau, constitute the main obsidian sources of the region. Hilly areas to the north of Söğütlü on the west of Erzurum, southwest of Palandöken Mountain, Pasinler and its surroundings are important territories where obsidian deposits have been identified. Pasinler district gained its geological character as a result of tectonic movements that took place in the late Pliocene and Pleistocene. External igneous rocks such as andesite, basalt and obsidian are widely distributed in the district and its immediate surroundings. Pasinler was one of our study areas during the surface surveys we initiated in the region in 1998. A large number of pottery and obsidian have been identified during our studies in Pasinler. Despite the advanced obsidian analysis methods, only a few of the centers in our study area were analyzed. In addition to important obsidian centers in the district and its surroundings, such as Kotandüzü, Pelitli and Tımar, it is thought as a result of researches implemented in Cin Castle, Çalıyazı Castle, Kavuşturan Castle and Sos Höyük that these centers may also be important obsidian workshops. Furthermore, it has been proved by realized analysis that the obsidian deposits and workshops in Pasinler partially met the needs of the nearby centers, and that they were also exchanged and traded with centers kilometers away.
\end{abstract}

Key Words: Erzurum, Obsidian, Pasinler, Workshop.

\section{Atıf İçin / Please Cite As:}

Ceylan, A., Akçelik, S. (2021). Yüzey Araştırmalar Işı̆̆ında Erzurum Pasinler İlçesinde Tespit Edilen Obsidyen Merkezleri ve Atölyeleri. Manas Sosyal Araştırmalar Dergisi, 10(3), 1964-1988.

Geliş Tarihi / Received Date: 09.07.2021

Kabul Tarihi / Accepted Date: 30.07.2021

\footnotetext{
${ }^{1}$ Prof. Dr. - Kırgızistan-Türkiye Manas Üniversitesi, alpaslan.ceylan@manas.edu.kg, bceylanerzurum@hotmail.com

(iD) ORCID:0000-0002-0533-905X

2 Doktora öğrencisi, Atatürk Üniversitesi,

iD ORCID:0000-0002-1569-432X
} 


\section{Giriş}

Ergimiş halde ve genellikle asidik özellik taşıyan magmanın hızlıca soğumasıyla oluşan volkanik kökenli kayaçlara obsidyen, obsidiyen ya da opsidiyen denir. Paleolitik Çağ'dan itibaren kullanımı başlayan obsidyen keskin yapısı, kontrollü kırlma özelliği, sürtülerek şekillendirilebilme yönü ve estetik görünümüyle birçok toplum tarafından alet yapımında hammadde olarak tercih edilmiştir (Balkan-Atlı, 2005, s. 2; Doğan, 2006, s. 132; Doğan, 2008, s. 151; Balc1 ve Altınbilek-Algül, 2017, s. 16). Obsidyen, işlevselliği nedeniyle çok eski dönemlerden beri (kazıyıcı, delici, ok ve mızrak ucu vb.)3 silah ve alet yapımında, süs eşyalarında (vazo, takı, ayna vb.) ve dekoratif malzemelerde (sıvalı kafataslarında, heykel ve figürlerin göz yuvalarında) kullanılmıştır (Esin, 1987, s. 79; Carter, 2006, s. 39; Kolankaya-Bostancı, 2008, s. 147; Doğanay ve Altaş, 2013, s. 254; Orange, Carter vd., 2013,s. 174; Güngördü, 2014, s. 104; Tsampiri, 2018, s. 28; Akın, 2019, s. 43).

Paleolitik Çağ'da kullanımı başlayan obsidyen, Neolitik Çağ'da ticarette adından söz ettiren bir meta haline gelmiştir. Tarih öncesi dönemlerde ticareti yapılan hammadde ve malların çoğu kısa süre dayanmış, bozulmuş ve arkeolojik veri olarak günümüze kadar gelememiştir. Ancak obsidyen, birçok hammaddeden farklı olarak uzak mesafelere hem hammadde hem de işlenmiş ürün olarak aktarımı sağlanmış nadir malzemelerden biridir (Özdoğan, 1994, s. 424; Doğan, 2008, s. 150-157; Doğan, 2006, s.132). Obsidyenin Neolitik Çağ'dan itibaren aktarımı başlamış bu da obsidyen yatakları dışındaki bölgelerde de kullanılmaya başlamasına neden olmuştur. Kalkolitik ve Tunç Çağlarında metal kullanımının yaygınlaşması obsidyen kullanım alanını daraltmıştır. Buna rağmen obsidyenin ayna ve vazo gibi prestij eşya özelliği ön plana çıkmıştır (Balkan-Atlı, 2005, s. 1-2; Balkan-Atlı, 2008, s. 128).

Anadolu, volkanizma açısından jeolojinin farklı zamanlarında etkin olduğu bir coğrafyadır. Anadolu, Üst Miosenden başlayarak Pliosen ve tüm Kuvaterner boyunca yoğun bir şekilde volkanizmaya maruz kalmıştır. Volkanların etkin olması Anadolu'nun Yakın Doğu'nun en zengin obsidyen yataklarına sahip olmasını sağlamıştır (Renfrew, Dixon vd., 1966, s. 35; Sagona ve Zimansky, 2018, s. 68). Anadolu sakinleri, obsidyeni birçok alanda kullanarak hem kendi ihtiyaçlarını karşılamış hem de hammaddesi olmayan merkezlere aktarımını sağlayarak değiş tokuş metası haline getirmişlerdir. Bu durum, Anadolu'nun önemli bir obsidyen etkileşim sahası olmasına neden olmuştur (Ercan, Yeğingil, Bigazzi, Oddone ve Özdoğan, 1990, s. 21; Altınbilek-Algül ve Balc1, 2010, s. 11; Balkan-Atlı, 2013, s. 8).

Anadolu'da Holosen zaman diliminde faal olan volkanizma, özellikle Doğu Anadolu Bölgesi ve Orta Anadolu'da yoğun bir şekilde etkili olmuştur. Doğu Anadolu Bölgesi'ndeki volkanik aktivitenin başlangıc1, kabuksal kırıklanma ve kalınlaşmayı meydana getiren Anadolu ve Arap plakasının çarpışmasıyla korele edilmektedir (Bigazzi, Yeğingil, 1997, s. 57; Algül, 2008, s. 32). Çarpışma kökenli riyolitik volkanizmay1 içinde barındıran yüzeylerdeki obsidyenler, Miyosen ve Pliosen yaşlı riyolitik bileşimdeki felsik lav akıntılarının kenar kısımlarında hızlıca soğumalarıla kristalleşmemiş bölümlerde oluşmuştur. Peneplen ya da peneplene yakın paleocoğrafya ile başlayan dönem tektonik gelişmeler ve volkanizma ile şekillenmiştir (Şaroğlu ve Güner,1981, s. 40; Keskin, Pearce ve Mitchell, 1998, s. 355 vd.).

Doğu Anadolu Bölgesi'nde geniş bir alanı kaplayan volkanik dağlar, yaklaşık 550 yl öncesine kadar aktif oldukları bilinmektedir (Bigazzi vd.,1997, s. 136). Bölgedeki volkanik dağlar, genel olarak Van Gölü Havzası'nda meydana gelen tektonik hareketler sonucunda doğu-batı doğrultulu volkanit ve kıvrımlarla oluşmuştur. Bölgenin zengin volkanik geçmişe sahip olması obsidyen yönünden zengin olmasına sebep olmuştur. Bölgedeki obsidyen yatakları, tarihin ilk dönemlerinde fark edilip çeşitli aletlerin yapımında yaygın bir şekilde kullanılarak ihtiyacı karşılamış ve üretim fazlası olduğunda da ticareti yapılmıştır (Akköprü, Mouralis, Robin, Kuzucuoğlu ve Erturaç, 2017, s. 50). Bölgedeki Ağr1 Dağ1 (5.137 m), Nemrut Dağ1 $(2.150 \mathrm{~m})$, Tendürek Dağ1 $(3291 \mathrm{~m})$, Meydan Dağ1 $(2320 \mathrm{~m})$ ve Süphan Dağ1 $(4.058 \mathrm{~m})$ gibi yanardağlar ve çevresi dışında Van, Erzurum (Pasinler, Güzelyurt, Ömertepe), Kars (Yağlıca, Sarıkamış), Erzincan (Boztepe) ve Bingöl gibi pek çok merkezde de obsidyen yatakları bulunmaktadır (Ercan vd., 1990, s. 19,21; Düring ve Gratuze, 2013, s. 173; Sagona ve Zimansky, 2018, s. 68). (Harita. 1).

Z. Yeğingil, G. Bigazzi, T. Ercan, M. Oddone ve M. Özdoğan gibi araştırmacılar yürüttükleri projelerle Doğu Anadolu Bölgesi’ndeki birçok arazide çalışmalarda bulunmuşlardırlar. Araştırmacılar, bölgedeki obsidyen alanlarını tespit ederek Fizyon Track yöntemini kullanıp obsidyen örneklerinin

\footnotetext{
3 Obsidyen kristal yapıda olmadığı için, keskin kenarları moleküler inceliğe ulaşır bu özelliği de tarihöncesi çağlarda ok ve mızrak ucu vd. gibi aletlerin yapımını kolaylaştırmıştır (Yıldırım ve Gökaşan, 2013, s. 57).
} 
analizini yaparak tarihlendirmelerini yapmışlardır. Fizyon Track yöntemiyle tarihlendirilen obsidyenlerle ilgili ilk sonuçlar G. Bigazzi tarafından yayınlanmıştır. 2006 yllında A. Sagona ve K. Kobayashi’nin bölgede sürdürdüğü çalışmalar dışında çok detaylı çalışmaların varlığından söz edilmemektedir. Ancak günümüzde yapılan yeni çalışmalar, bölgedeki obsidyen ile ilgili araştırmalara yeni bir ivme kazandırmış ve kazandırmaya da devam etmektedir.

\section{Erzurum ve yakın çevresindeki obsidyen ile ilgili çalışmalar}

Erzurum-Kars Bölümü’nün jeolojik özelliklerine bakıldığında andezit, bazalt ve obsidyen gibi dış püskürük kayaçlarının geniş bir yayılımının olduğu görülmektedir. Bu alanlar, kısmen Neojen lavlar kısmen de Dördüncü Zamana ait genç patlamalarla meydana gelmiştir (Kayserili, 2014, s. 55). (Harita. 2).

Erzurum ve çevresinin arkeolojik açıdan zengin bir potansiyele sahip olması bu coğrafyada araştırmalar yapılmasına neden olmuştur. Erzurum prehistoryası ile ilgili ilk araştırma İ. K. Kökten tarafindan yapılmıştır. Erzurum ve çevresindeki Paleolitik çalısmalar İ. K. Kökten, H. Z. Koşay, M. S. Şenyürek ve K. Alot tarafindan yürütülmüştür. Erzurum-Pasinler arasındaki Hamamderesi ile Dumlu Bölgesinde yer alan Şıpşıp Mağarasında Paleolitik Çağ verileri tespit edilmiştir. Dumlu Köyü ve çevresinde yüzeyde de bazalttan yapılmış Alt Paleolitik tipi Sheelleen alet bulunmuştur. Yine Erzurum-Pasinler demiryolunun kuzeyindeki yamaçlarda Üst Paleolitik'e tarihlendirilen siyah obsidyenden yapılmış Aurignacian bir yonga tespit edilmiştir (Kökten, 1943, s. 604; Kökten, 1944, s. 659-680; Şenyürek,1944, s. 350 vd.; Kökten, 1947, s. 431 vd.; Kökten, 1953, s. 189; Koşay, 1984, s. 12 vd.; Pehlivan, 1984, s. 1 vd.; Erkmen ve Ceylan, 2003, s. 17 vd.; Ceylan, 2008, s. 107; Ceylan ve Günaşdı, 2017,s. 317,318).

Erzurum ve çevresinde yapılan kazı çalışmaları 1942 yılında H. Z. Koşay tarafından Karaz kazısıyla başlamışır. 1942'de başlayan kazı çalışmaları 1944'e kadar devam etmiştir. Karaz Höyük'te yapılan çalışmalarda 26 adet yontmataş buluntusu tespit edilmiştir. Bu buluntuların sadece 7 tanesi obsidyendir. Tespit edilen obsidyenlerden 5'i Erzurum Müzesinde teşhir salonu ve depoda diğer 2'si de Ankara Arkeoloji Müzesindedir. Bu iki eser, 13 nolu ve 51 nolu kazıyıcı tarafindan obsidyen biçak olarak tanımlanmıştır (Koşay-Turfan, 1959, s. 349 vd.).

1960 yllında H. Z. Koşay ve H. Vary tarafindan tek sezonluk Pulur (Ömertepe) Höyük kazısı yapılmıştır. Yapılan araştırmalara göre Pulur (Ömertepe)'da tespit edilen obsidyenlerin Turnagöl Dağ1 yamaçlarından taşınarak günlük ihtiyaçlara uygun bir şekilde işlendiği düşünülmektedir (Sözer, 1963, s. 210). H. Z. Koşay, höyükte Kalkolitik Çağ’a tarihlenen çakmaktaşından ve madenden yapılan buluntuların az olmasına rağmen obsidyen oranının fazla olduğunu tespit etmiştir. Kazılarda obsidyen ve çakmaktaşından deliciler, kesiciler, ok uçları ve doğal taştan yapılmış ezgi taşları ele geçirilmiştir. Buluntuların 205 adedinin obsidyen 2 adedinin de çakmaktaşı olduğu kayda geçmiştir. Kazıyıcılar, obsidyen kütlelerinin Pulur (Ömertepe)'un batısındaki dăg yamaçlarından getirilerek burada işlendiğini öne sürmüşlerdir. Ayrıca kapların firınlandıktan sonra obsidyen kazıyıcılarla zig-zaklar çizilerek süslemelerinin yapıldığ́ düşünülmektedir (Koşay ve Vary,1964, s.1 vdd; Koşay, 1964, s. 91 vd.; Koşay, 1984, s. 1 vdd.). Yapılan çalışmalar, Pulur (Ömertepe)'un Erzurum ve çevresindeki önemli obsidyen merkezlerinden biri olduğunu ortaya koymaktadır (Brennan,1995, s. 25 vd.; Brennan, 2000, s. 128 vd.).

1961 yılında H. Z. Koşay ve ekibi tarafından tek sezonluk Güzelova Höyük kazısı yapılmıştır. Höyükte, çakmaktaşı ve obsidyenden yapılmış aletler bulunmuştur. Güzelova'daki küçük buluntuların büyük bir bölümünü taş ve kemik aletler oluşturmaktadır. Sileksten ve obsidyenden yapılmış ok uçları, perdah taşları, kemik eserler, çuvaldızlar, bızlar, iğneler ve kemiklerden yapılmış ağırşaklar tespit edilmiştir. Kazı envanterine göre aletlerin 50 adedi obsidyenden 4 adedi de çakmaktaşından yapılmıştır. (Sözer, 1963, s. 210; Koşay ve Vary, 1967, s. 1 vd.).

1971 yllında G. Pasquaré, Erzurum ve çevresinde yaptığı çalışmalarda Başköy’ün kuzeybatısında 600 $\mathrm{m}$ yükseklikte büyük bir piroklastik volkan olduğundan bahsetmiştir. Bu volkan tabakalarında $15-20 \mathrm{~cm}$ kalınlığında tamamen saf obsidyen akıntıları tespit etmiştir. Ayrıca G. Pasquaré, Kıble Tepe ve çevresinde obsidyen varlığından bahsedip Güzelyurt (Tambura)'taki obsidyenlerden analiz örnekleri almıştır (Chataigner, Işıklı, Gratuze ve Çil, 2013, s. 4). Tabya Dağ1 ve Kıble Tepe volkanik sidner konilerinde yapılan araştırmalarda vitrik tüflerle beraber tabakalarda obsidyen akıntıları da gözlenmiştir (Çelik, 2005, s. 52). Tabya Dağ1, Kıble Tepe ve Güzelyurt (Tambura)'ta yapılan tarihlendirme analizlerine göre merkezlerin $6.90 \pm 0.32$ milyon yll yaşta oldukları görülmüştür. Erzurum ve çevresinde T. Ercan ve ekibi 1996 y1lında 
obsidyen depoları tespit etmiştir. Daha sonra G. Bigazzi ve ekibi, yeni merkezler tespit edip bu merkezlerden aldıkları obsidyen örneklerinin yaşlandırma analizlerini yapmıştır (Bigazzi, Yeğingil vd. 1996, s. 521 vd.; Bigazzi, Yeğingil vd.,1997, s. 64; Chataigner, Poidevin ve Arnaud, 1998, s. 527; Akköprü vd., 2017, s. 52).

Erzurum'un batısında yer alan Pulur (Ömertepe)'daki obsidyen yatağının varlığıyla ilgili çalışmaları G. Bigazzi ve ekibi yapmıştır. Araştırmalar sonucunda merkezdeki obsidyenlerin camlaşmıss, kaliteli ve siyah renkte oldukları tespit edilmiştir. Ayrıca Pulur (Ömertepe)'un Ar/Ar $8.4 \pm 0.2$ milyon yıl yaşta olduğu belirlenmiştir (Bigazzi vd.,1997, s. 64; Chataigner vd., 1998, s. 527; Chataigner vd., 2013, s. 5). Ancak 2006 ylında K. Kobayashi, Kuzeydoğu Anadolu'da obsidyen kaynaklı yaptığı araştırmalarda tespit ettiği obsidyenlerin düşük kaliteli, küçük boyutlu ve alet yapımına uygun olmadığını ileri sürmüştür (Kobayashi ve Sagona, 2008, s. 187).

\section{Pasinler ve çevresinin jeolojik yapısı ve obsidyen yayılımı}

Pasinler (Hasankale) ilçesi, Erzurum ilinin 39 km doğusunda bulunan Hasandede Dağının eteğinde Pasin Ovasında kurulmuştur. Deniz seviyesinden 1740 m yükseklikteki Pasinler, Erzurum'dan yaklaşık 130 m alçakta yer almaktadır. Deveboynu volkanik eşiği ile Aras Vadisi arasında kalan ova, Pasin/Hasankale Ovası olarak adlandırlır. Pasin Ovası ve çevresi bugünkü jeomorfolojik karakterini Pliosen sonu ve Pleistosen içinde meydana gelen tektonik hareketler sonucunda kazanmıştır. Pleistosen başlarında gerçekleşen tektonik hareketler bazı kısımların yükselmesine bazı kısımların da çökmesine neden olmuştur. Çökmeler sonucu meydana gelen Pasin Ovası, Aşağı ve Yukarı Pasin olarak ikiye ayrılmaktadır. Aşağ1 Pasin Ovası olarak tanımlanan yer Horasan Havzasıdır. Aşağı Pasin Ovasının etrafı dağlarla çevrilidir ve şekillenmesinde Aras Nehri önemli bir rol oynamışır. Yukarı Pasin Ovasını Pasinler ilçesi oluşturmaktadır. Yukarı Pasin Ovasının doğusunda Köprüköy ve Horasan, batısında Erzurum, kuzeyinde Tortum ve Narman güneyinde de Karayazı ve Tekman bulunmaktadır (Atalay,1978:24; Balkaya,1995: 1vdd.; ErkmenCeylan: 2003:17; Özgül, 2011b, s. 94; Üngör, 2012, s. 432; Ceylan, N., 2016, s. 657).

Pasinler ve çevresindeki yükseltiler ortalama 2200-2300 m olduğu için Pasinler, plato morfolojisi sergilemektedir. Pasinler'de büyük hacimli piroklastik akıntı, döküntü ürünleri ve ara katmanlarda bulunan daha küçük hacimli lav akıntıları bulunmaktadır. Yapılan K/Ar yaş tayinlerine göre, Pasinler üzerindeki volkanizmanın 7.8 milyon yıl önce başladığını göstermektedir (Keskin,1994:39; Keskin,1996-1997, s. 61; Keskin, 1998, s. 143). Pasinler civarında Pliosen ve Kuvaterner Zamana ait birçok volkanik bazaltik lav akışları ve andezitik domlar bulunmaktadır. Pasinler ve çevresinde yoğun obsidyen oluşumlar tespit edilmiştir. Pliosen yaşlı obsidyen yatakları, volkan konilerindeki andezitik lavlar ve tüflerle birleşiktir (Bozkuş, 1993, s. 32 vd., Bigazzi vd., 1997, s. 64). Ayrıca obsidyenler; obsidyen domlarında, alüvyonlar içinde ve piroklastiklerde bulunmaktadır (Akköprü vd., 2017, s. 52).

Pasinler’in dağ silsilesine bakıldığında, etrafi dağlarla çevrili oldukça korunaklı yapıda olduğu söylenilebilir. Ovanın batısında yer alan dağlar kuzeyden güneye doğru Kargapazarı Dağları (3288 m), Şahvelet Dağları (2922 m), Deveboynu Dağları (2400 m), Oluklu Dağı (2500 m), Alibaba Dağı (3100 m), Nalbantlar Dağ1 (3100 m), Sancaklar Dağ1 (3030 m), Sakaltutan (2940 m), Ambarc1 Dağ1 (2850 m), Küçük Postlubaba- Büyük Postlubaba (2800 m), Kandil Dağ1 (2100 m), Açgın Dağ1 (2800 m), İçligöl Dağ1 (2810 m)'dir (Sür,1961, s. 115).

Kargapazarı Dağının doğusunda ve Pasin Ovasının kuzeyindeki bulunan volkanik dağ Ziyaret Tepe $(2700 \mathrm{~m})$ 'dir. Ziyaret Tepe'nin güneyinde ovanın ortasında sivrilen Hasanbaba $(2200 \mathrm{~m})$ volkanik tepesi bulunmaktadır. Yeniköy plato düzü $(2430 \mathrm{~m})$ ve Çilligül Dağları $(2250 \mathrm{~m})$ ovanın kuzeydoğusunda yer alan diğer volkanik plato dağlarıdır. Dağların yapısını volkanik ara tabakalı miosen tortulları, andezit/trakit aglomerası ve bazalt lavları oluşturmaktadır (Sür, 1961, s. 115). Diğer önemli Pasinler volkaniklerden biri de Pasinler'in güneyindeki Tizgi (Aşıtlar) Mahallesindedir. Tizgi (Aşıtlar) Mahallesinin kuzeyindeki obsidyenler, özellikle akarsu çökellerinde, riyolitik domlarda ve kırıntılar içinde yüzeylenmiştir. Buradaki obsidyenler Ar/Ar yöntemine göre $6.0 \pm 5.5$. ve $5.5 \pm 1.1$ yaş aralıklarında olduğu tespit edilmiştir (Bigazzi vd.,1997, s. 64; Chataigner vd., 1998, s. 527).

Pasinler'in kuzeybatısında bulunan Kargapazarı Dağlarının güney yönündeki Pasin Ovasına doğru akan Büyükdere/Malikom Deresi, ovadaki tarım arazilerine hayat vermektir. Kuzey-güney doğrultuda uzanan Büyükdere'nin açtı̆ı geniş vadi ve çevresinde irili ufaklı obsidyen yumruları tespit edilmiştir (Chataigner vd., 2013, s. 5). Bu dere vadisinde obsidyen yumrular üzerinde A. Sagona fazla ayrintilı olmayan bir araştırma yapmıştır (Sagona, Erkmen vd., 1996, s. 14). Büyükdere Vadisinin özellikle doğu 
yamacında obsidyen yumrularının çok olduğu görülmektedir (Foto 1). Buradaki obsidyenler cams1 parlaklıkta ve genellikle siyah renktedirler. Ayrıca alet ve silahların çıkarıldığı bazı obsidyen parçalarının ağırlığ1 8.5- 9 kilo civarında olduğu tespit edilmiştir (Belli, 2000, s. 304).

Arkeolojik ve jeolojik araştırmalar sonucunda Pasinler ve yakın çevresinde tespit edilen obsidyen merkezleri ve atölyeleri alfabetik olarak aşağıda belirtilmeye çalısılmıştır.

\section{Cin kalesi}

Pasinler ilçesinin $11 \mathrm{~km}$ kuzeydoğusundaki Kurnuç (Büyükdere) Mahallesinin $1 \mathrm{~km}$ kuzeyindeki kale, yöre halkı tarafindan Cin Kalesi olarak adlandırılmıştır. Deniz seviyesinden 1870 m yükseklikteki kalenin doğusu Büyükdere Vadisi'ne açılmaktadır. Kale andezit kayalardan oluşan bir zemin üzerine inşa edilmiştir. Kale duvarlarının dış yüzeylerinde kabaca işlenmiş andezit taşların, çevredeki zengin andezit yataklarından temin edildiği düşünülmektedir. Kalenin güneyi dik olmakla birlikte oval bir plan gösterir. Kalenin sur duvarları büyük ölçüde yıkıldığı için kalenin planı hakkında bilgi edinmek oldukça zordur. Kalenin doğu eteklerinde yerleşim amaçlı yapıldığı düşünülen konut kalıntılarına rastlanılmıştır. Konut duvarlarında kullanılan ve dış yüzeyleri kabaca işlenmiş taşlar, kale duvarlarında kullanılan taşlara nazaran daha küçüktür. Kalede bulunan keramikler Tunç Çağı, Demir Çağı ve Orta Çağ özelliği göstermektedir. Kalenin en önemli özelliği Büyükdere Vadisi'nde yer alan bol miktardaki ham obsidyen yumrularının plakalar halinde taşınarak burada işlenmiş olmasıdır. Çevrede dağınık halde bulunan işlenmiş ve yarı işlenmiş obsidyen parçalarının ve yongaların varllğı, Cin Kalesi’nin önemli bir obsidyen atölyesi olduğunun bir göstergesidir. Öyle ki Cin Kalesi obsidyen atölyesi, Kalkolitik Çă̆’dan beri Pasin Ovası ve yöredeki diğer merkezlerin obsidyen ihtiyacını karşılamıştır. Merkezde tespit edilen obsidyenden yapılmış alet ve silahlar, siyah renkte ve cams1 parlaklıktadır (Belli, 2000, s. 304-305; Belli, 2001, s. 207-208; Ceylan,2001, s. 73; Kozbe, Ceylan vd.,2008: Cin Kalesi; Ceylan, 2008, s. 65; Özgül, 2011a, s. 132; Ceylan ve Günaşd1, 2018, s. 154). Analiz için merkezden obsidyen örnekleri alınmıştır (Foto 2-3/Çizim 1).

\section{Çalıyazı/Çalyazı kalesi}

Pasinler ilçesinin $17 \mathrm{~km}$ kuzeyinde Çalıyazı Mahallesinin $2 \mathrm{~km}$ batısındaki kale, 2363 rakımda yer almaktadır. Kalenin sur duvarlarının büyük bir kısmı ortadan kalkmış olmasına rağmen ana kayaya oyulmuş sur duvar yatakları günümüze kadar gelebilmiştir. Kalenin bazı bölümlerinde duvar kalıntısı olduğu düşünülen yapılar bulunmaktadır. Kalenin doğu kesiminde $110 \mathrm{~cm}$ civarında bir duvar yapısında harç kullanılmadığ1 tespit edilmiştir. Kalenin iç kesiminde taşların kesilmesiyle oluşturulmuş bir koridorun olduğundan söz edilebilir. Kalenin batı kesiminde, kapı girişi olarak tahmin edilen bir kalıntı bulunmaktadır. Kalenin ön kısmında kaçak kazıyla $2 \mathrm{~m}$ derinliğe kadar inildiği görülmektedir. Kalenin erken döneme ait olduğu düşünülen üç mezar saptanmıştır. Kalede yaptı̆̆ımız araştırmalarda işlenmiş obsidyen ve küçük bir parça keramik parçası bulunmuştur. (Üngör, Bingöl vd., 2014, s. 66; Ceylan ve Günaşd1, 2018, s. 158). Çalıyazı ve çevresinde A. Sagona ve K. Kobayashi’nin yaptığı çalışmalar esnasında obsidyen bir çekirdek tespit edilmiştir. $\mathrm{Bu}$ merkezin önemli bir obsidyen atölyesi olabileceği düşünülmektedir (Kobayashi ve Sagona, 2008, s.187). Merkezdeki obsidyenler, çoğunlukta siyah renkte ve parlak oldukları saptanmıştır. Ayrıca merkezden analiz için obsidyen örnekleri alınmıştır (Foto. 4-5/Çizim 2).

\section{Kavuşturan kalesi}

Pasinler ilçesinin $8 \mathrm{~km}$ kuzeyindeki Kavuşturan Mahallesinin $2.5 \mathrm{~km}$ güneybatısında, Serçeboğazı Mahallesinin yaklaşı $1 \mathrm{~km}$ güneydoğusunda yer alan kale, $1850 \mathrm{~m}$ yükseklikte bulunmaktadır. Kale, Pasin Ovasının en yüksek noktasında ve ovaya hâkim bir konumdadır. Surları kiklopik teknikle yapılan kalenin iç kısmındaki mimari kalıntılar çok belirgin bir şekilde görülmektedir. Merkezde İlk Tunç Çağ ve Orta Çağ keramiklerinin yanı sıra bol miktarda işlenmiş obsidyen tespit edilmiştir. Kale ve çevresinde obsidyen yatağı bulunmamasına rağmen kaleye, çevredeki yataklarından obsidyenin getirildiği düşünülmektedir (Ceylan, 2004, s. 265-266; Kozbe, Ceylan vd., 2008: Kavuşturan; Ceylan, 2008, s. 138; Özgül, 2011a, s. 134; Ceylan ve Günaşd1, 2018, s. 264). Bu kalenin önemli bir obsidyen atölyesi olabileceği düşünülmektedir. Parlak siyah renkteki obsidyenlerin çoğunlukta olduğu merkezden analiz için obsidyen örnekleri alınmıştır (Foto. 6-7/Çizim 3). 


\section{Kotandüzü obsidyen merkezleri I -II}

Pasinler ilçesinin $15 \mathrm{~km}$ kuzeyindeki Kotandüzü Mahallesi, iki önemli obsidyen yatağına ev sahipliği yapmaktadır. Obsidyen yataklarının ilki köy sınırlanı içinde bloklar halinde ve parlak siyah, alacalı siyah ve kırmızı renkte oldukları gözlenmiştir (Chataigner vd., 2013, s. 7; Üngör, Bingöl vd., 2014, s. 67; Ceylan, 2015, s. 319). İkinci merkez, köyün $15 \mathrm{~km}$ kuzeyinde ve köy sınırları içerisinde yer almaktadır. Bu merkezdeki obsidyenlerin, küçük parçalara ayrılarak yol yapım çalışmalarında kullanıldıkları bilinmektedir (Üngör, Bingöl vd., 2014, s. 67). Merkezdeki obsidyenler genellikle siyah renkte ve cams1 parlaklıkta oldukları tespit edilmiştir. Analiz için merkezden obsidyen örnekleri alınmışır (Foto. 8-9/ Çizim 4).

\section{Pelitli kalesi ve obsidyen merkezi}

Pasinler ilçesinin 24 km kuzeyinde Pelitli Mahallesinin kuzeyinde 2237 m rakımda konumlanan kale, çift surlu kale örneklerindendir. Stratejik bakımdan kuzey ve doğusundan ulaşım sağlanması kalenin önemli özelliklerindedir. Kale mimari yapı özelliğiyle Orta Çağ görünümündedir. Kalenin iç mimari yapıları orijinalliğini korumaktadır. Kalenin yerleşim yerine uzak olması kaleyi daha korunaklı hale getirmiştir. Kalede bol miktarda keramik ve obsidyen tespit edilmiştir. Kaledeki keramikler Demir Çağ ve Ortaçağ’a aittir. Obsidyen kaynağının bulunduğu tepe, Pelitli Kalesi'nin de olduğu yerdedir. Yapılan araştırmalara göre Pelitli Kalesi, hem obsidyen kaynağı hem de işleme alanı özelliği taşımaktadır (Üngör, Bingöl vd., 2014, s. 68; Ceylan, 2015, s. 313-314; Ceylan ve Günaşd1, 2018, s. 309). Merkezdeki obsidyenler genellikle siyah renkte ve camsı parlaklıkta oldukları tespit edilmiştir. Ayrıca analiz için merkezden obsidyen örnekleri alınmıştır (Foto. 10-11/ Çizim 5).

\section{Sos (Yiğittaş1) höyük}

Pasinler Ovasında konumlanmış olan ve Pasinler ilçesinin 14 km batısında Sos (Yiğittaşı) Mahallesinin içinde yer alan höyügün kuzeyinden Aras Nehri kollarından olan Çöğender Deresi geçmektedir. Ova tabanından $20 \mathrm{~m}$ yükseklikteki höyügün kuzey kesimi dışındaki kısımlarında modern köy evleri bulunmaktadır. Höyük, özellikle erozyon ve toprak çekilmesi sonucunda tahrip olmuş ve kuzey yamaçları da dereye doğru kaymıştır.

K. Kökten bölgede yaptı̆̆1 yüzey araştırmalarında Sos Höyük'ten bahsetmemiştir. H.Z. Koşay, bölgede yürüttüğü kazılarda Sos Höyüğü tespit etmiştir. Ancak höyükle ilgili ayrıntılı bilgi verilmemiş yayınlarda da sadece haritalarda gösterilmiştir (Koşay ve Turfan 1959, s. 349 vd.). Daha sonra A. Sagona başkanlığında Melbourne Üniversitesi adına 1994 yılında höyükte kazı çalışmaları başlamış, 2000 yılında son aktif çalışmalarla sona ermiştir. Sos Höyük'te yapılan kazılarda; yerleşim biçimi, mimari kalıntılar, flora ve fauna örnekleri, yemek kapları, kişisel eşya (küpe, toka) ve aletler yönünden oldukça zengin bir kültürel geçmişe sahip olduğu görülmüştür. Höyükte yontulmuş obsidyen aletler, ahşap aletler, dövme taşları ve bazalt sürtme taşları tespit edilmiştir. Yontmataş endüstrisinde kullanılan çok sayıdaki obsidyen alet ve yapım tekniğinin her aşamasına ait parçaların olması obsidyen aletlerinin höyükte yapıldığına işaret etmektedir. Ayrıca höyük, $20 \mathrm{~km}$ uzağında bulunan Aras Nehri ve kollarından obsidyen parçaları ve yumruları toplanılabilecek yakınlıktadır (Koşay ve Vary,1964,s. 7; Sagona, 1984, s. 248-249,344; Sagona, 1995, s. 193-218; Sagona, Erkmen vd.,1995, s. 27 vd.; Sagona, 1996a, s. 133-134; Sagona, 1996b, s. 27-52; Sagona, 1997a, s. 140-141; Sagona, 1997b, s. 186-191; Sagona, 1998b, s. 33-38; Sagona, 1998a, s. 249; Sagona, 1999, s. 205-206; Sagona ve Sagona, 2000, s. 143-144; Sagona, 2000, s. 329-330, 333-335; Ceylan, 2005, s. 25; Kobayashi, 2007, s. 141 vd.; Kozbe, Ceylan vd., 2008, Sos; Sagona, 2010, s. 42 vd.). (Foto. $12-$ 13/ Çizim 6).

\section{Timar obsidyen yatakları}

Pasinler ilçesinin $11 \mathrm{~km}$ kuzeydoğusundaki Tımar Mahallesi, Pasin Ovasında tespit edilen en önemli obsidyen yataklarından biridir. Merkezde yapılan araştırmalarda işlenmiş ve yarı işlenmiş obsidyenlerin çevresindeki merkezlere kaynaklık edebilecek nitelikte olduğu tespit edilmiştir (Ceylan, 2004, s. 266; Kozbe, Ceylan vd. 2008:Tımar; Ceylan, 2008, s. 143). Merkezdeki obsidyenler, çoğunlukta siyah renkte ve 
parlak çok az bir kısmının da siyah ve mat oldukları saptanmıştır. Analiz için merkezden obsidyen örnekleri alınmışır (Foto. 14-15/ Çizim 7).

\section{Sonuç}

Doğu Anadolu Bölgesi’nin önemli obsidyen merkezlerinden biri de volkanikleri Üst Miyosen ile Alt Pliyosen Zaman aralığına tarihlendirilen Erzurum ve çevresidir Erzurum'un obsidyen potansiyeline bakıldığında doğusunda Pasinler ve çevresi, batısında Tabya Dağı ve Kıble Tepe, güneybatısında Başköy önemli kaynaklardır. Erzurum Ovasındaki merkezlerin birbirine yakın olması, eskiçağ toplumlarının alet yapımında bu merkezlerin kaynaklarından yararlanmalarına olanak sağlamıştır. Çok büyük ve dağınık halde bulunan obsidyen yataklarının varlı̆̆ı bölgedeki obsidyen yoğunluğunu ortaya koymaktadır.

Pasinler'de yer alan Kotandüzü, Pelitli ve Tımar gibi önemli obsidyen merkezlerinin varlığ1, çevresinde bulunan merkezlerin obsidyen ihtiyacının karşılanmasında önem arz etmektedir. Büyükdere Vadisi'nin doğusundaki obsidyenlerin plakalar halinde Cin Kalesine taşınarak burada işlenmesi kalenin önemli bir obsidyen atölyesi olmasını sağlamıştır. Çalıyazı Kalesi ve Kavuşturan Kalesinde yapılan araştırmalar ve veriler bu kalelerin de önemli birer obsidyen atölyesi olabileceğine işaret etmektedir. Sos Höyük'te de hem işlenmiş hem de işlenme aşamalarının göstergesi olan obsidyen parçalarının olması höyügün önemli bir obsidyen atölyesinin olduğunu göstermektedir. Ayrıca Pasinler ve yakın çevresinde yaptığımız yüzey araştırmalarında Altınbaşak Höyük, Bulamaç Höyük, Hanahmet Yayla Yerleşmesi, Karakale, Kurbançayır Yerleşmesi, Marifet (Sürbahan) Kaya Mezarı, Tilkitepe (Karavelet) Höyük, Yastıktepe Höyük, Topdağı (Küçükdağ) Kalesi, Urumçi Yerleşmesi, Yukarı Çakmak Yerleşmesi ve Ziyarettepe Yerleşmesi gibi merkezlerde de obsidyen buluntuları tespit edilmiştir.

Pasinlerdeki işlik alanlarından çıkarılan obsidyenler, yontucular tarafından işlenip hem bölge ihtiyacını karşılamış hem de bölge dışındaki yerleşimlerle takas ve ticareti yapılmıştır. Pulur, Sos, Tepecik ve Güzelova'da yapılan araştırmalarda merkezlerden alınan obsidyen örneklerinin çoğunun Pasinler kaynaklı olduğu tespit edilmiştir. Pulur Höyük'ten alınan 22 adet obsidyen örneğinin 15 adedinin Pasinler kaynağ1 olmasına rağmen höyüğün yakınındaki Söğütlü kaynağından obsidyen temin edilmeme nedeni tam olarak netlik kazanmamıştır.

Pasinler kaynaklı obsidyenler, sadece Erzurum ve çevresindeki merkezlerde değil kilometrelerce uzaklıktaki merkezlerde de tespit edilmiştir. Domuztepe'de yapılan araştırmalarda obsidyenlerin farklı kaynaklardan getirildiği saptanmıştır. Domuztepe'ye genellikle Bingöl-Van Havzası yataklarından obsidyen getirilmiştir (Campbell, Carter, Healy, Anderson, Kenned ve Whitcher, 1999, s. 415). Ayrıca höyüğe, Orta Anadolu'dan, (Nenezi Dağ, Göllü Dağ) Kuzeydoğu Anadolu'dan (Erzurum/Pasinler) ve Ermenistan'dan (Arteni) obsidyen temin edilmiştir (Healey, 2007, s. 173-175).

Tell Kurdu'da yapılan araştırmalarda obsidyen dilgiciklerin Pasinler ya da Muş kaynaklı olduğu ileri sürülmüştür. Daha sonra yapılan araştırmalarda merkezlerden alınan obsidyen örnekleri karşılaştırılmıştır. Analizler sonucu Tell Kurdu'daki obsidyenlerin Pasin kaynaklı olduğu kesinleşmiştir (Chataigner vd., 2013, s. 12-13). Ayrıca Kuzey Suriye'nin obsidyen ihtiyacının büyük bir kısmı Doğu Anadolu'daki Bingöl, Muş, Kars/Sarıkamış, Van, Erzurum/Pasinler gibi merkezlerden karşılanmışır (Healey, 2007, s. 172,175).

Günümüzde birçok bilim insanının üzerinde çalıştı̆̆ı, Pasinler ve çevresindeki obsidyen yataklarılyla ilk çalışmalar A. Sagona ve K. Kobayashi ile başlamıştır. Ekibimizle 20 yılı aşkın bir süredir aralıksız bir şekilde yapmış olduğumuz yüzey araştırmalarında Pasinler ve yakın çevresindeki merkezlerde ham obsidyen ve işlenmiş obsidyen verileri tespit edilmiştir. Tespit edilen merkez ve atölyelerden analizler için obsidyen örnekleri alınmıştır. İlk dönem kazıları ve günümüzde yürütülen yüzey araştırmaları arttırılarak daha kapsamlı çalışmalar yapılarak bölgenin obsidyen potansiyeli daha fazla ortaya konulmaya çalışılmaktadır.

\section{Kaynakça}

Akın, G. (2019) Insanm Prehistorik dönemde kulland̆ğ hammaddeler. Ankara: Alter Yayınları.

Akköprü, E., Mauralis, vd. (2017). Doğu Anadolu'daki obsidiyen kaynak alanlarının belirlenmesinde jeomorfolojik ve volkanolojik göstergelerin önemi”. Türkiye Jeoloji Bülteni 60/1, 49-61.

Algül, G. C.., (2008). Çanak çömleksiz̨den çanak çömlekli Neolitik Döneme geçis sïrecinde obsidyen teknolojisi, (Doktora Tezi). İstanbul Üniversitesi Sosyal Bilimler Enstitüsü. İstanbul. 
Altınbilek-Algül, Ç. ve Balc1, S. (2010). Obsidyen ticaretinin merkezi olarak Kültepe. Türk Eskiçă̆ Bilimleri Enstitüsü Haberler Dergisi 30, 11-13.

Atalay, İ. (1978). Erzurum Ovası ve çevresinin jeolojisi ve jeomorfolojisi. Ankara: Sevinç Matbaası.

Balc1, S. ve Altınbilek- Algül, Ç. (2017). Polished obsidian objects: examples of prestige 1tems from Kültepe. Türk Eskiçăg Bilimleri Enstitüsü Haberler Dergisi 16,15-29.

Balkan-Atl1, N. (2005). Paleolitikten günümüze obsidyen. Türk Eskiçağ Bilimleri Enstitüsü Haberler Dergisi 19, 1-3.

Balkan-Atl, N. (2008). Obsidyenin geçmişten günümüze yolculuğu yarı bilimsel yarı içerik (ezoterik) bir yazı. Prof. Dr. Haluk. Abbasoğlu'na 65. yaş armağanı I, 127-131

Balkan-Atlı, N. (2013). Kaletepe obsidyen atölyesi kazısı ve Göllüdağ obsidyen projesi. Arkeolojik Buluntular Işı̆gnda Niğde Taribi Sempozyum Bildirileri, 8-15.

Balkaya İ.S. (1995) En eski Căğlardan Urartu'nun yıkılısıına kadar Hasankale ve çevresi, (Yüksek Lisans Tezi). Atatürk Üniversitesi Sosyal Bilimler Enstitüsü. Erzurum.

Belli, O. (2000). Doğu Anadolu'da saptanan obsidyen yatakları ve atölyeleri, Türkiye Arkeolojisi ve İstanbul Üniversitesi (1932-1999), (Edt. O. Belli),Ankara: Başak Matbaacıllk, 301-307.

Belli, O. (2001). 1999 Yılında Doğu Anadolu Bölgesinde Urartu baraj, gölet ve sulama kanallarının araştırılması, XVIII. Arastırma Sonuclar Toplantısı- II. Ankara, 205-218.

Bigazzi, G., Yeğingil, Z. vd. (1997). Doğu Anadolu'daki obsidyen içeren volkaniklerin fizyon track yöntemiyle yaş tayini. Türkiye Jeoloji Bülteni 40/2. 57-72.

Brennan, P. V. (1995). Obsidian in the Bayburt-Erzurum area, eastern Anatolia. AbrNabrain, Supplement 5, 27-36.

Brennan, P. V. (2000). Obsidian from Volcanic Sequences and Recent Alluvial Deposits Erzurum District, NorthEastern Anatolia: Chemical Chracterization and Archaeological Implications. Ancient Near Eastern Studies 37, 128- 152.

Bozkuş, C. (1993). Pasinler-Horasan (Erzurum) Havzası doğusunun stratigrafisi. MTA 115, 30-32.

Campbell, S., Carter, E., Healy, E., Anderson, S., Kenned, A. ve Whitcher, S. (1999). Emerging Complexity on the Kahramanmaraş Plain, Turkey: Domuztepe Project, 1995-1997, American Journal of Archaeology 103/3, s. 395418.

Carter, T. (2006). Cam Şehri: Çatalhöyük’te Obsidyen'in Rolü. Topraktan Sonsu§̨luğa Çatalböyük. (Edt. M. Haydaroğlu). İstanbul: Yapı Kredi Yayınları, 39-45.

Ceylan, A. (2001). 1999 Yılı Erzincan ve Erzurum yüzey araştırmaları. XVIII. Araștırma Sonuçlar Toplantısı- II, 71-82.

Ceylan, A. (2004). 2002 Yılı Erzincan, Erzurum ve Kars illeri yüzey araştırmaları. XXIV. Araştırma Sonuçları ToplantısıII, 263-272.

Ceylan, A. (2005). The Erzincan, Erzurum and Kars region in the iron age. Anatolian Iron Ages V, 21-29.

Ceylan, A. (2008). Doğu Anadolu araştırmalar I Eræ̧urum-Eræ̨incan-Kars-Iğdır (1998-2008). Erzurum: Güneş Vakfi Yayınları.

Ceylan, A. (2015). Doğu Anadolu araştırmalar II Erzurum-Eræincan-Kars-Iğdır (2008- 2014). Erzurum: Atatürk Üniversitesi Yayınları.

Ceylan, A.ve Günaşdı, Y. (2017). Erzurum ve çevresindeki Urartu yazıtlarının tarihi açıdan değerlendirilmesi. Akademik Tarih ve Düşünce Dergisi IV. / XIII, 313-350.

Ceylan, A. ve Günaşd1, Y. (2018). Eræurum'un Eskiçağ kaleleri. Erzurum: Atatürk Üniversitesi Yayınları.

Ceylan, N. (2016). Pasin Ovasının kuzeye açılan iki tarihi yolu. Uluslararası Sosyal Araştırmalar Dergisi 9/43, 656-671.

Chataigner, C., Işıkl, M., Gratuze, B. ve Çil, V. (2013). Obsidian sources in the regions of Erzurum and Kars (northeast Turkey): new data. Archaeometry.1- 24. 
Chataigner, C., Poidevin, J.L. and Arnaud, N. O. (1998). Turkish occurrences of obsidian and use by prehistoric peoples in the near east from 14.000 to 6000 BP. Journal of Volcanology and Geothermal Research 85, 517-537.

Çelik, B. (2005). Doğu Anadolu obsidyenlerinin fiąyon iz̨leri yöntemiyle tariblendirilmesi ve yaş düzeltme çalısmalar. (Yüksek Lisans Tezi). Çukurova Üniversitesi Fen Bilimleri Enstitüsü. Adana.

Doğan, İ. B. (2006). Tarihöncesi dönemde ticaretin göstergeleri ve değgs tokus modelleri. (Yüksek Lisans Tezi). İstanbul Üniversitesi Sosyal Bilimler Enstitüsü. İstanbul.

Doğan, İ. B. (2008). Tarihöncesinde ticaret ve değiş tokuş. İstanbul: Arkeoloji ve Sanat Yayınları.

Doğanay, H., ve Altaş, N. T. (2013). Doğal kaynaklar. Erzurum: Pegem Yayınevi

Düring, B.S. ve Gratuze, B. (2013). Obsidian exchange networks in prehistoric Anatolia: new data from the Black Sea region. Paléorient 39/2, 173-182.

Ercan, T., Yeğingil, Z., Bigazzi, G., Öddöne, M., ve Özdoğan, M. (1990). Kuzeybatı Anadolu obsidyen buluntularının kaynak belirleme çalışmaları. Jeoloji Mühendislĭgi 36, 19-32.

Erinç, S. (1953). Doğu Anadolu coğrafyası, İstanbul: İstanbul Üniversitesi Yayınları.

Erkmen, M. ve Ceylan, A. (2003). 2001 Pasinler kalesi kazısı. XIII. Müze Calısmalar ve Kurtarma Ką̧lar Sempozуити.17-28.

Esin, U. (1994). Akeramik Neolitik evrede Aş1klı Höyük. 11.Türk Tarih Kongresi. Ankara: Türk Tarih Kurumu Basımevi.

Healey, E. (2007). Obsidian as an indicator of inter-regional contacts and eexchange: three case-studies from the Halaf period. Anatolian Studies, 57, 171-189.

Kayserili, A. (2014). Eræurum şebrinin kültürel coğrafyası (maddi kültür öğelerine göre). Erzurum: Atatürk Üniversitesi Yayınları.

Keskin, M. (1996-1997). Pasinler platosundaki çarpıșma-kökenli volkanik istifin volkano-stratigrafisi jeokimyası ve magma odası işlemlerinin petrolojik modellemesi: Erzurum-Kars platosu, Kd Anadolu. İstanbul Yer Bilimleri Dergisi 10/ 1-2, 59-77.

Keskin, M. (1998). Erzurum-Kars platosunun çarpışma kökenli volkanizmasının volkanostratigrafisi ve yeni k/ar yaş bulguları 1şı̆̆ında evrimi, Kuzeydoğu Anadolu. MTA 120, 135-157.

Keskin, M., Pearce, J.A. and Mitchell, J. G. (1998). Volcano-stratigrapyhy and geochemistry of collision-related volkanism on the Erzurum-Kars plateau, northeastern Turkey. Journal of Volcanology and Geothermal Resarch 85, 355-404.

Kobayashi, K. (2007). An Obsidian refitting from Sos höyük, eastern turkey. ANES 44. s.141-154.

Kobayashi, K. ve Sagona, A. (2008). A Survey of Obsidian Sources in the Provinces of Erzurum, Erzincan, Rizeand Bitlis 2006. XXV. Araştırma Sonuclar Toplantısı, 185-197.

Kolankaya- Bostanc1, N. (2008). Ege Bölgesinde Obsidyen Ticareti. III. ve IV. Arkeolojik Arastırmalar Sempozyumu,(I. Yalçınkaya). Ankara: Ankara Üniversitesi Dil Tarih, Coğrafya Fakültesi Yayınları, 147-164.

Koşay, H. Z. (1948). Karaz sondajı. Türk Tarih Kongresi III. 165- 169.

Koşay, H. Z. (1964). Pulur ve Güzelova (Erzurum) Araştırmaları. Atatürk Konferanslar Bildirileri I, 91-94.

Koşay, H. Z. (1984). Eræ̧urum ve ģevresinin dip tarihi. Ankara: Türk Kültürünü Araştırma Vakfı Yayınları.

Koşay, H. Z. ve Turfan, K. (1959). Erzurum Karaz kazısı raporu. Belleten 23\91, 349- 413.

Koşay H. Z. ve Vary H. (1964). Pulur kąısı, 1960 mevsimi çalıs̆malar raporu, Ankara: Atatürk Üniversitesi Yayınları.

Koşay, H. Z. ve Vary, H. (1967). Gürelova kazısı. Ankara.

Kozbe G., A.Ceylan vd. (2008). Cin kalesi Türkiye Arkeolojik Yerleşmeleri-6a-b (TAY) Demir Çağları. İstanbul.65

Kozbe G., A.Ceylan vd. (2008). Kavuşturan Türkiye Arkeolojik Yerleşmeleri-6a-b (TAY) Demir Çağları. İstanbul.138. 
Kozbe G., A.Ceylan vd. (2008). Tımar. Türkiye Arkeolojik Yerleşmeleri-6a-b (TAY) Demir Çağları. İstanbul.143.

Kökten, İ. K. (1944). Orta, Doğu ve Kuzey Anadolu'da yapılan tarih öncesi araştırmalar. Belleten VIII/32, 659-680.

Kökten, İ. K. (1945). Yılında Türk Tarih Kurumu adına yapılan tarih öncesi araştırmalar. Belleten 11/43, 431-472.

Kökten, İ. K. (1953). 1952 Yılında Yaptığım Tarih Öncesi Araştırmalar. Dil Tarih ve Coğrafya Fakültesi Dergisi $\mathrm{XI} / 2-3-4$.

Orange, M., Carter, T. ve Le Bourdonnec. (2013). Sourcing Obsidian from Tell Aswad and Qdeir 1 (Syria) by SEMEDS and EDXRF: Methodological İmplication. Comptes Rendus Palevol 12, 173-180.

Özdoğan, M. (1994). Obsidian in Anatolia: an archaeological perspective on the status of research. Archaeometry. 423431.

Özgül, O. (2011a). Eskiçağda yukar Aras vadisi. (Doktora Tezi).Atatürk Üniversitesi Sosyal Bilimler Enstitüsü. Erzurum.

Özgül, O. (2011b). Pasin ovasının tarihi coğrafyası. Sosyal Bilimler Enstitüsü Dergisi 8, 91-106.

Pehlivan, M. (1984). En eski çağlardan Urartu'nun yıkadar Eræurum ve çevresi. (Doktora Tezi). Atatürk Üniversitesi Sosyal Bilimler Enstitüsü. Erzurum.

Renfrew, C., Dixon, J.E. vd. (1966). Obsidian and early cultural contact in the near east. Proceedings of Prehistoric Society $32,30-72$.

Sagona, A. ve Zimansky, P. (2018). Arkeolojik veriler ışı̆̆ında Türkiye'nin en eski kültürleri MÖ 1.000.000-550, İstanbul: Arkeoloji Sanat Yayınları.

Sagona, A. (1984). The caucasian region in the early bronze age. BAR 214. Oxford.

Sagona, A. (1995). Excavations at Sos Höyük-1994 first preliminary report. Anatolian Studies 45, 193-218.

Sagona, C. Sagona, H. vd. (1996a). Excavations at Sos Höyük-1994. XVII. Kaz̨ Sonuçlar Toplantısı-I, 129-150.

Sagona, A., Erkmen, M., vd. (1996b). Excavations at Sos Höyük, 1995: Second Preliminary Report. Anatolian Studies 46,27-52.

Sagona, A. Erkmen, M. (1997a). Excavations Sos Höyük 1995. XVIII. Ką̨ Sonuclar Toplantısı- I, 137-143.

Sagona A.-Erkmen M. vd. (1997b). Excavation at Sos Höyük-1996:third preliminary report. Anatolica 23, 181-226.

Sagona, A. (1998a). Excavations Sos Höyük 1996. XIX. Ką̧ Sonuclar Toplantısı-I. 245- 250.

Sagona, A. Sagona, C. vd. (1998b). Excavations at Sos Höyük 1997: Fourth Preliminary Report. Anatolian Studies 24, 31-64.

Sagona, A., Erkmen M. vd. (1999). Excavations at Sos Höyük, 1997. XX. Kazı Sonuclar Toplantısı-I, 205-206.

Sagona, A. (2000). Sos Höyük and the Erzurum region in late prehistory a provisional chronology for northeast Anatolia. Chronologiesdes Paysdu Caucase et de L'Euphrateaux IVe - IIIe Millenaires: Actesdu Colloqued 'Istanbul, 16- 19 Decembre 1998, Varia Anatolica XI, İstanbul.329-373.

Sagona, A. (2010). Erzurum yakınında antik bir yerleşim Sos höyük, Geçişsten Geleceğe Armağan, Erzurum: Arkeolojik Kültürel ve Estetik Yansımalar. 42-49.

Sözer, N. (1963). Erzurum Ovasında tarih öncesi kır yerleşmesi. Türk Coğrafya Dergisi 22-23, 205-216.

Sür, Ö. (1961). Pasinler Ovası ve çevresinde jeomorfolojik müşahedeler. Türk Coğrafya Dergisi 21,112-122.

Şaroğlu, F. ve Güner, Y. (1981). Doğu Anadolu'nun jeomorfolojik gelişimine etki eden öğeler; jeomorfoloji, tektonik, volkanizma ilişkileri. Türkìye Jeoloji Kurumu Bülteni 24,39-50.

Şenyürek, M. (1944). Tebliğler: Anadolu'da bulunan iki yeni Paleolitik alete dair bir not. Dil Tarih ve Coğrafya Fakültesi Dergisi, II/2.

Tsampri, M. (2018). Obsidian in the prehistoric aegean: trade and uses. Bulletin of the Geological Society of Greece 53/1, 28-49. 
Üngör, İ., Bingöl, A., vd. (2014). 2012 Yılı Erzincan ve Erzurum İlleri Yüzey Araştırmaları. XXXI. Araştırma Sonuçlar Toplantısı II, 61- 77.

Üngör, İ. (2012)Urartu Kale Kazıları (Pasinler Kalesi) Excavations on Pasinler castle 2001. Uluslararası Doğu Anadolu Güney Kafkasya Kültürleri Sempozyumu Bildiriler II. 432-442.

Yıldırım, M. ve Gökaşan, E. (2013). Mühendisler için jeoloji bilgileri, İstanbul: Yıldız Teknik Üniversitesi.

\section{EXTENDED ABSTRACT}

Due to its location on the world, Anatolia is one of the most active regions in all geological periods. Anatolian territory is young in terms of geological structures, that is, it is a territory that has recently begun to take shape. The activity of Tertiary and Quaternary, old volcanisms in many parts of Anatolia helped to enrich its obsidian deposits. Obsidian sources are found especially around volcanoes, such as Ağrn, Nemrut, Tendürek and Süphan mountains in Eastern Anatolia and around Erciyes and Hasan mountains in Central Anatolia in the form of large lava flows and of blocks/pieces of different sizes within agglomerates and related types. Additionally Erzurum, Erzincan, Kars, Bingöl, Rize, the region between Bolu and Ankara, Kütahya and territory around İzmir Menderes Airport are centers rich in obsidian.

The richest region of Turkey in terms of volcanic topography is Eastern Anatolia. Geological and geomorphological structure of Eastern Anatolia was formed in III. and IV. Geological Periods. Researchers such as Z. Yeğingil, G. Bigazzi, T. Ercan, M. Oddone and M. Özdoğan have worked on many fields in Eastern Anatolia through the projects they implemented. The researchers revealed obsidian fields in the region and determined their dates by analyzing obsidian samples through the Fission Track method.

The surface forms of Erzurum, which constitutes the western half of the Erzurum-Kars Plateau in the northeast of Eastern Anatolia, have been largely shaped in the III. Geological Period. The rich archaeological and geological potential of Erzurum has led researches to conduct studies in this territory. The first Paleolithic studies in Erzurum and its surroundings were conducted by K. Kökten, H. Z. Koşay, M. S. Şenyürek and K. Alot. Data from the Paleolithic Age were discovered in Hamamderesi between Erzurum-Pasinler and Şışsıp Cave located in Dumlu Region. A Lower Paleolithic type of Sheelleen tool made of basalt was also found on the surface in the vicinity of the Dumlu Village. Moreover, an Aurignacian flake made of black obsidian dated to the Upper Paleolithic was also found on the slopes to the north of the Erzurum-Pasinler railway.

Considering the obsidian potential of Erzurum Pasinler and its surroundings to the east, Tabya Mountain, Kible Heights in the west, Başköy in the southwest are significant deposits. Additionally, in surface studies in Erzurum and its vicinity, data on obsidian were found in centers, such as Karaz, Pulur, Güzelova. The great and widespread existence of obsidian sources in Erzurum and its vicinity proves the intense concentration of obsidian.

Pasinler District was founded on the slopes of the Hasandede Mountain, which lies $39 \mathrm{~km}$ to the east of Erzurum city. It is divided to two as Lower and Upper Pasin Plane. The territory called Lower Pasin Plane is Horasan Basin. The Aras River has a great role in the formation of the plane covering an area of $120 \mathrm{~km} 2$. The territory called Upper Pasin Plane is Pasinler District. The plane covers an area of $350 \mathrm{~km} 2$. Çobandere Bridge constitutes the border between Lower and Upper Pasin Plane. Pasinler is on the crossing point of historical roads. The limited transportation on the north-south axis of Pasinler (after Deveboynu Crossing) made the settlements in region an unavoidable crossing point on the east-west axis.

The fertile conditions that Pasinler possessed in prehistoric times made it a preferable place for many communities as a settlement. The rich water potential of Pasinler has increased the fertility of agricultural lands. Aras River has an important place in shaping the plain. The large tributary that Aras River divides Pasinler plain into two and joins Köprüköy-Çobandede bears the same name as the plain. This tributary is named as Phasis/Pasin Stream by the people. Aras River joins with Pasin/Phasis Stream and reaches Horasan region. Other important streams of Pasinler are: Pusudere, Deliler, Büyükdere, Tuylar, Esendere, Nalbant, Ügümü, Yağan, Güçlü and Güzelhisar streams.

The oldest information about Pasin Plain, especially about the Upper Pasin, started with two tools found in the area called Hamamderesi, and it was determined that these tools are from the Paleolithic Age. Furthermore, many settlements belonging to the culture called "Karaz Culture" in the Early Bronze Age 
were identified. Pasinler is an important center, where various states/nations, such as Hurri, Hayasa, Urartu, Persian, Macedonian, Seleucid, Parthian, Roman, Byzantine, Georgian, Saltuklu, Seljuk, Anatolian Seljuk, İlhanlı, Çobanoğulları, Celayirliler, Eratnaoğulları, Karakoyunlu, Akkoyunlu, Safavid and Ottoman states/nations existed.

Pasinler district gained its geological character as a result of tectonic movements that took place in the late Pliocene and Pleistocene. External igneous rocks such as andesite, basalt and obsidian are widely distributed in the district and its immediate surroundings. In the surveys we conducted in Pasinler and its surroundings, Altınbaşak Höyük, Bulamaç Höyük, Cin Castle, Çalıyazı Castle, Hanahmet Yayla Settlement, Karakale, Kavuşturan Castle, Kurbançayır Settlement, Kotandüzü, Marifet (Sürbahan) Rock Tomb, Pelitli Castle, Sos Höyük, Tımar, Tilkitepe (Karavelet) Höyük, Yastıktepe Höyük, Topdağı (Küçükdağ) Castle, Urumçi Settlement, Yukarı Çakmak Settlement, and Ziyarettepe Settlement are among the centers, where obsidian finds were discovered. The existence of important obsidian deposits in places, such as Kotandüzü, Pelitli and Timar, is important in terms of supplying the obsidian demands of the centers around it. Researches carried out in Cin Castle, Çalıyazı Castle and Kavusturan Castle demonstrate that these castles may have been important obsidian workshops. In addition, the presence of obsidian remains in Sos Höyük, which are both processed and indicative of the processing stages, signify that the mound had an important obsidian workshop. Obsidians originating from Pasinler have been detected not only in Erzurum and in its vicinity, but also in centers many kilometers away. Hence, the obsidians extracted from the workshops in Pasinler were processed by the sculptors, and they both the met the demand in the region, and they were exchanged and traded was made with the settlements outside of the region. 


\section{EKLER}

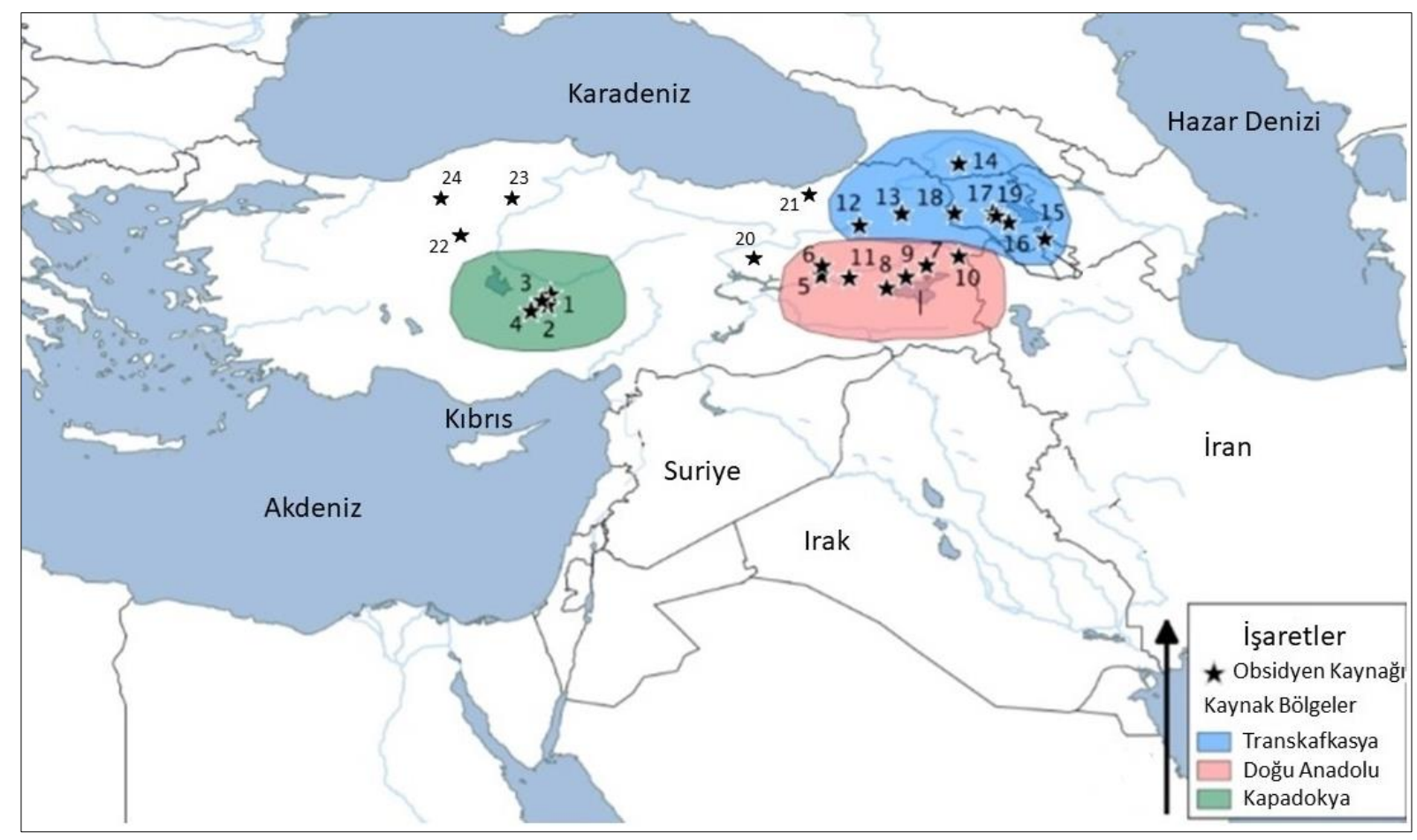

Harita 1. Obsidyen Kaynaklar ve Dağgllm

1-Acıgöl 2-Göllü Dağ 3-Nenezidağ 4-Hasan Dağ1 5- Bingöl A 6- Bingöl B 7-Meydan Dağ1 8-Nemrut Dağ1 9- Süphan Dağı 10- Tendürek Dağ1 11- Muş 12- Erzurum (Pasinler) 13- Kars (Sarıkamış) 14Kojun Dağı 15- Sjunik 16- Gegham 17- Gutansar 18- Arteni 19- Hatis 20- Erzincan (Boztepe) 21- Rize (İkizdere) 22- Ankara 23- Çankırı (Orta/Sakaeli) 24- Bolu (Gerede/Yağlar) 


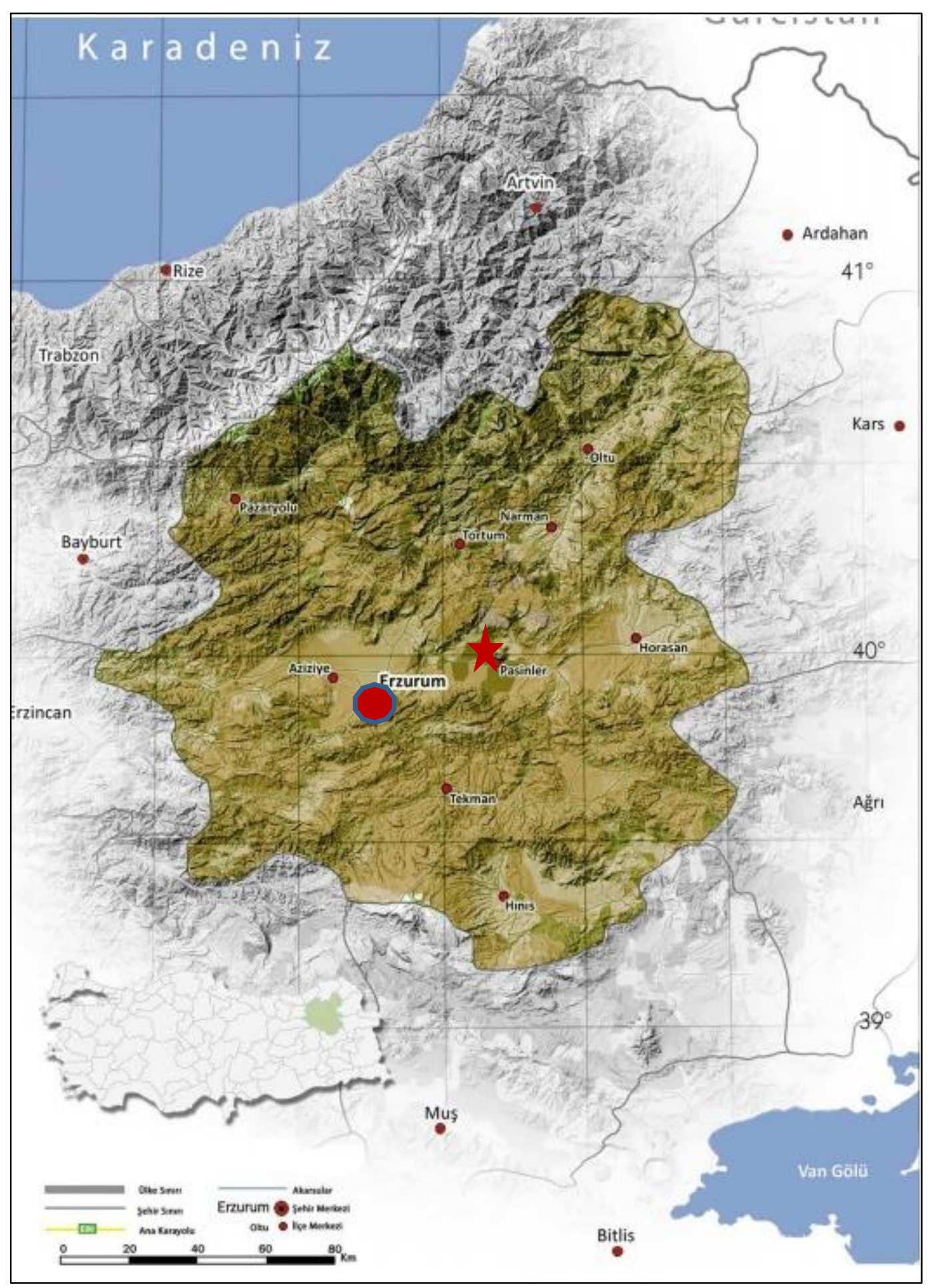

Harita 2. Erzurum Il Haritast 


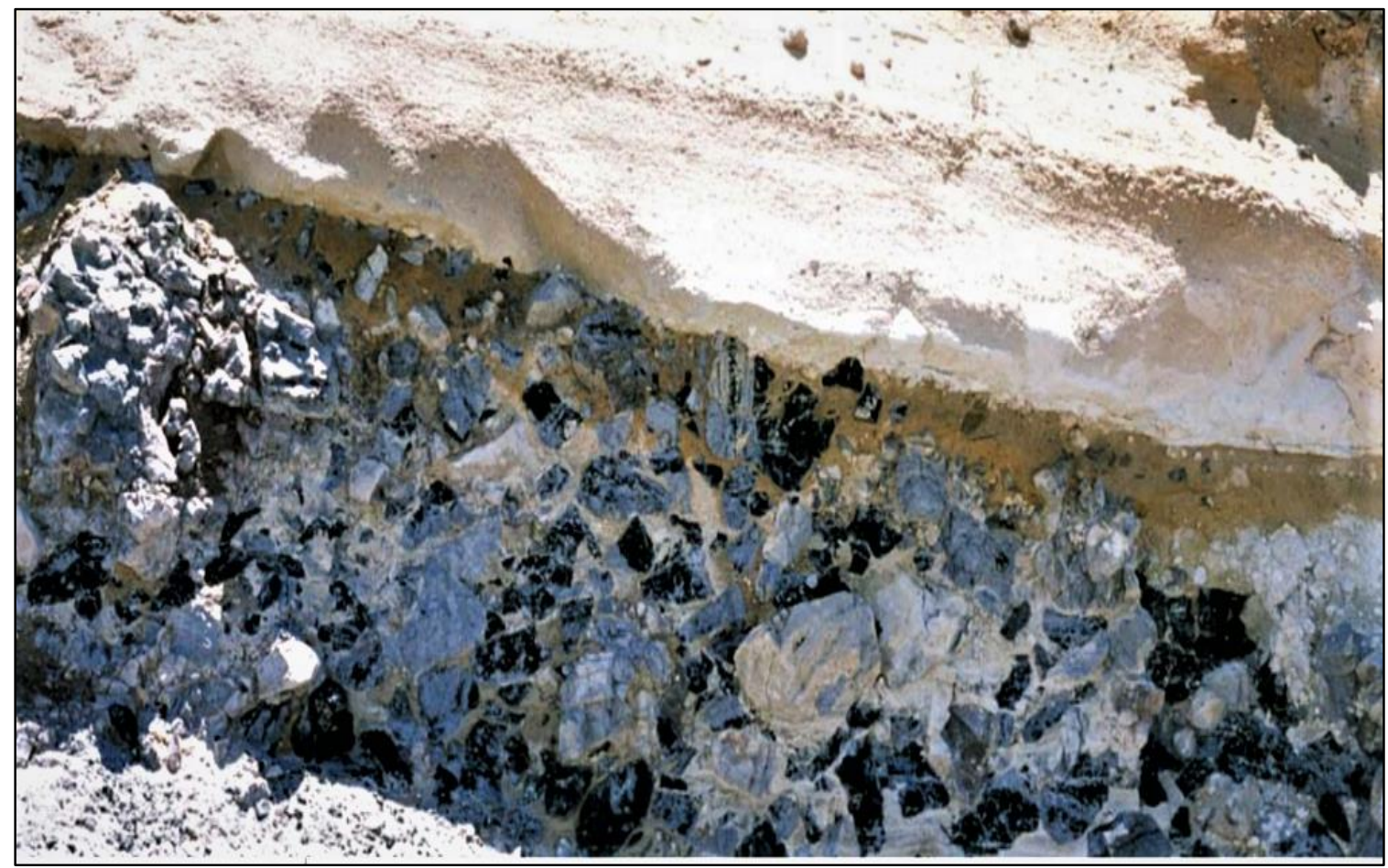

Foto 1. Büyülkdere Obsidyen Kaynağı (Sagona, 2010)

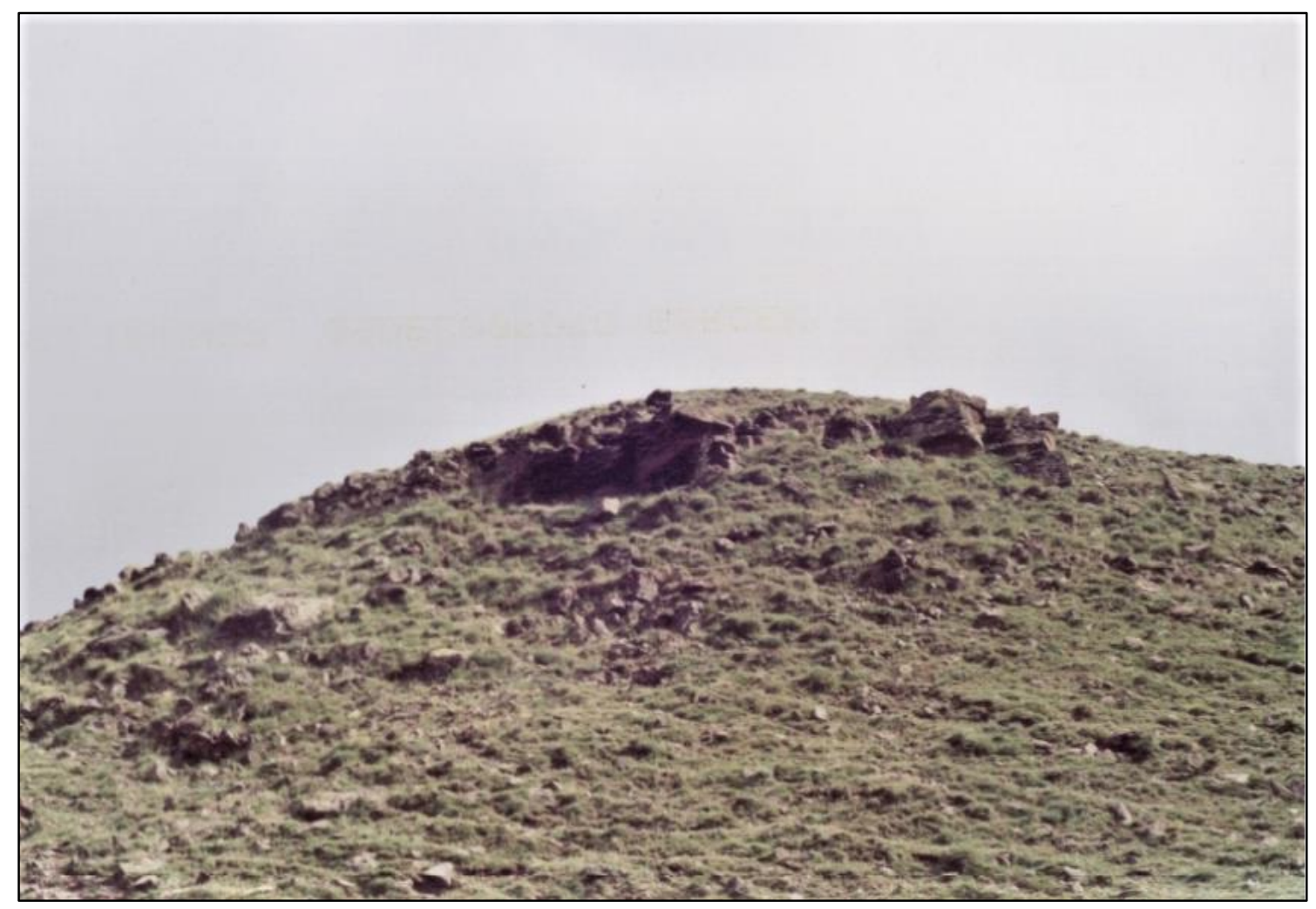

Foto 2. Cin Kalesi Genel Görünümü 


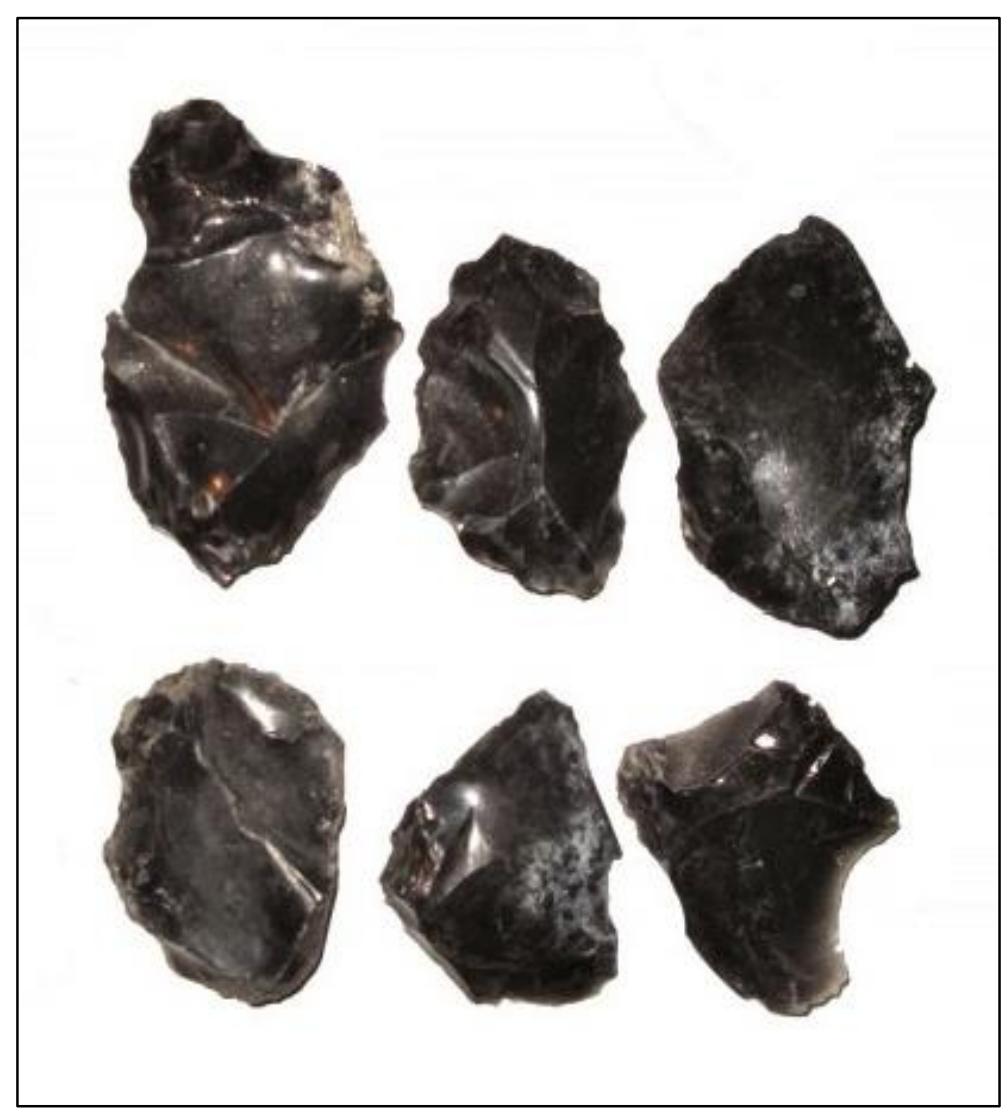

Foto 3. Cin Kalesi Obsidyen Örnekleri

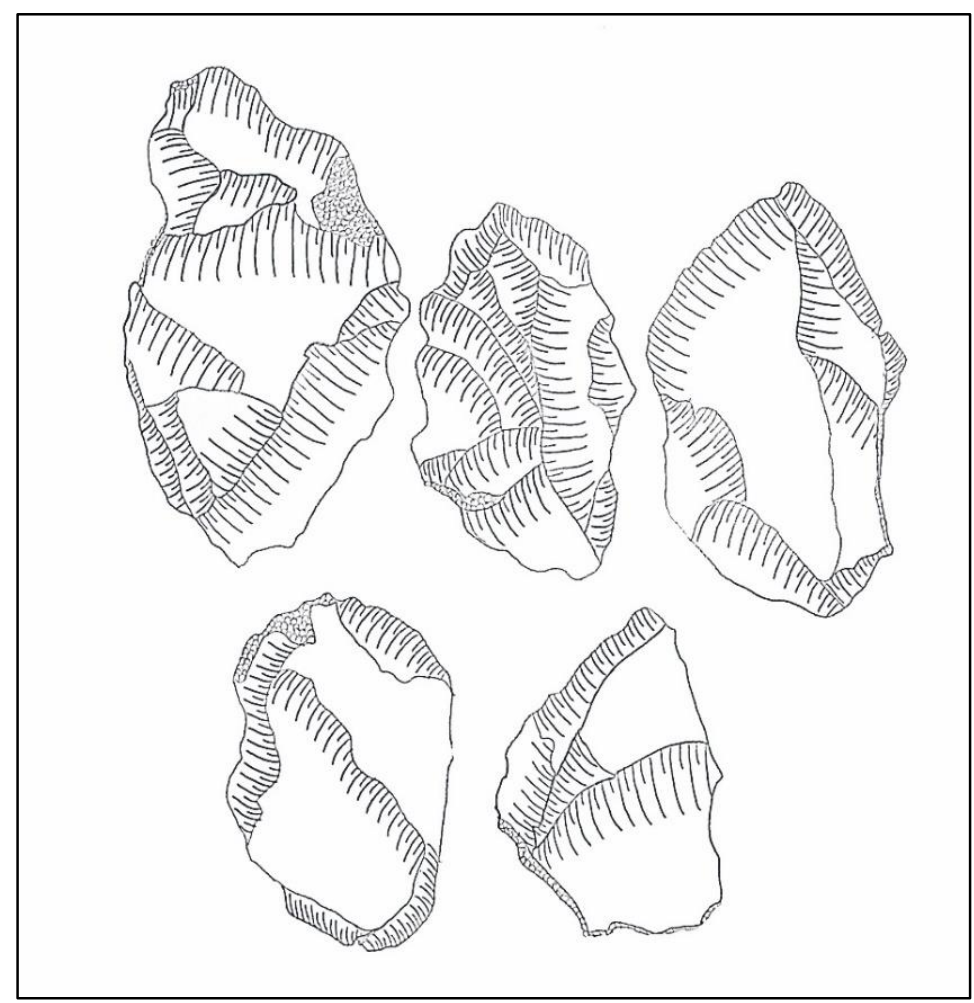

Çizim 1. Cin Kalesi Obsidyen Ömekleri Çiચ̨imi 
CEYLAN ve AKÇELİK

Yüzey Araştırmalar Işı̆̆ında Erzurum Pasinler İlçesinde Tespit Edilen Obsidyen Merkezleri ve Atölyeleri

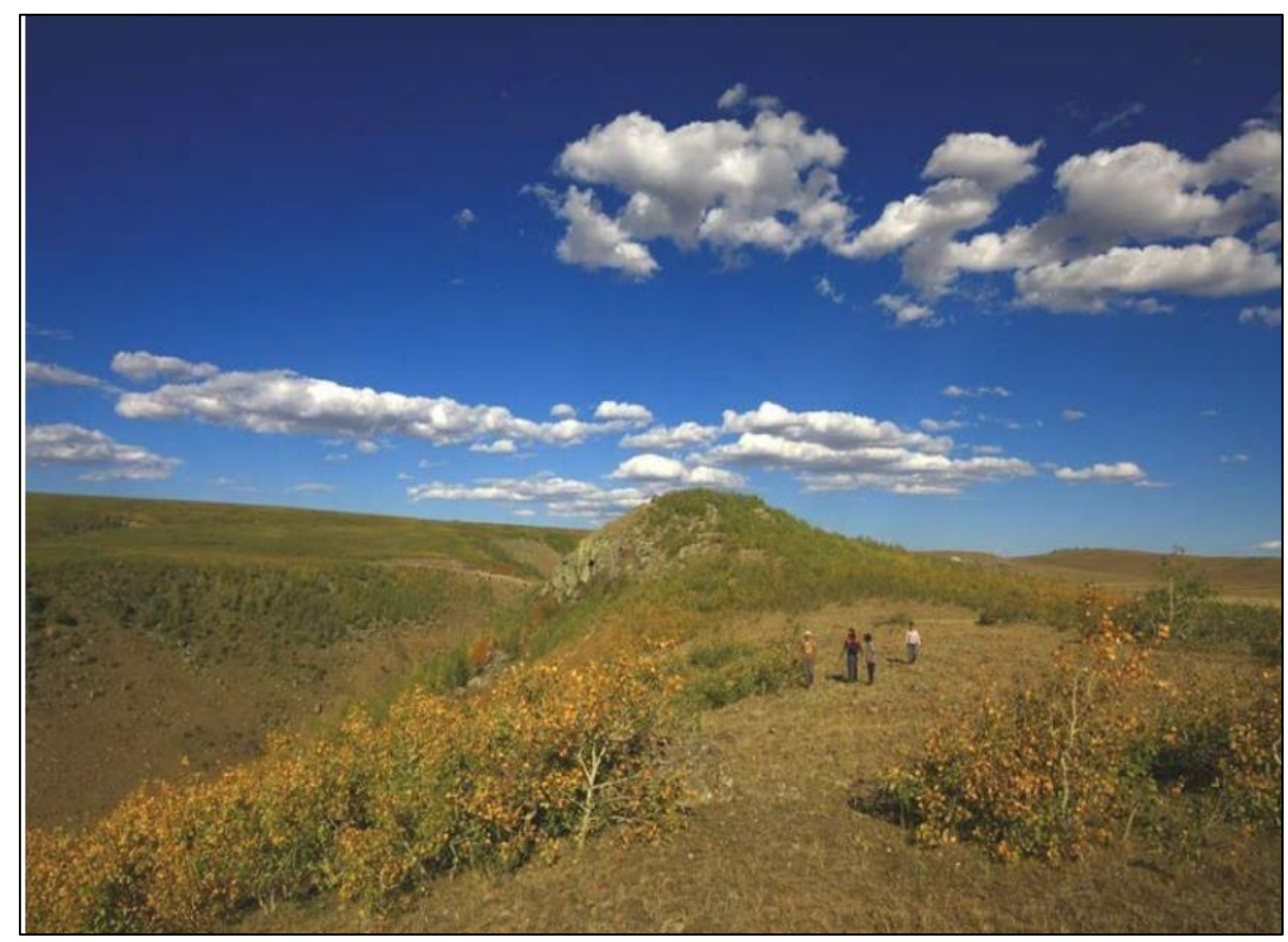

Foto 4. Callyaz̨ Genel Görünümü

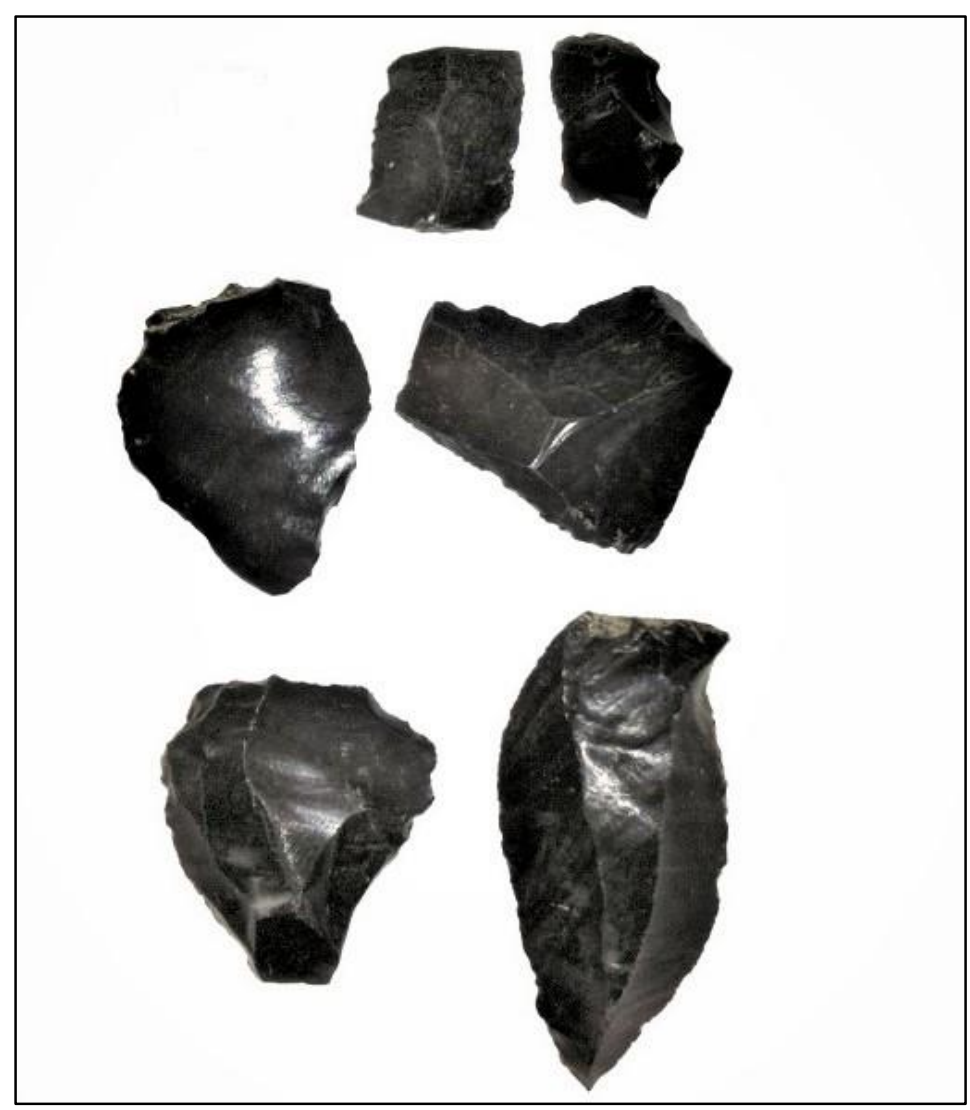

Foto 5. Calyaz?/ Calyar Kalesi Obsidyenleri 


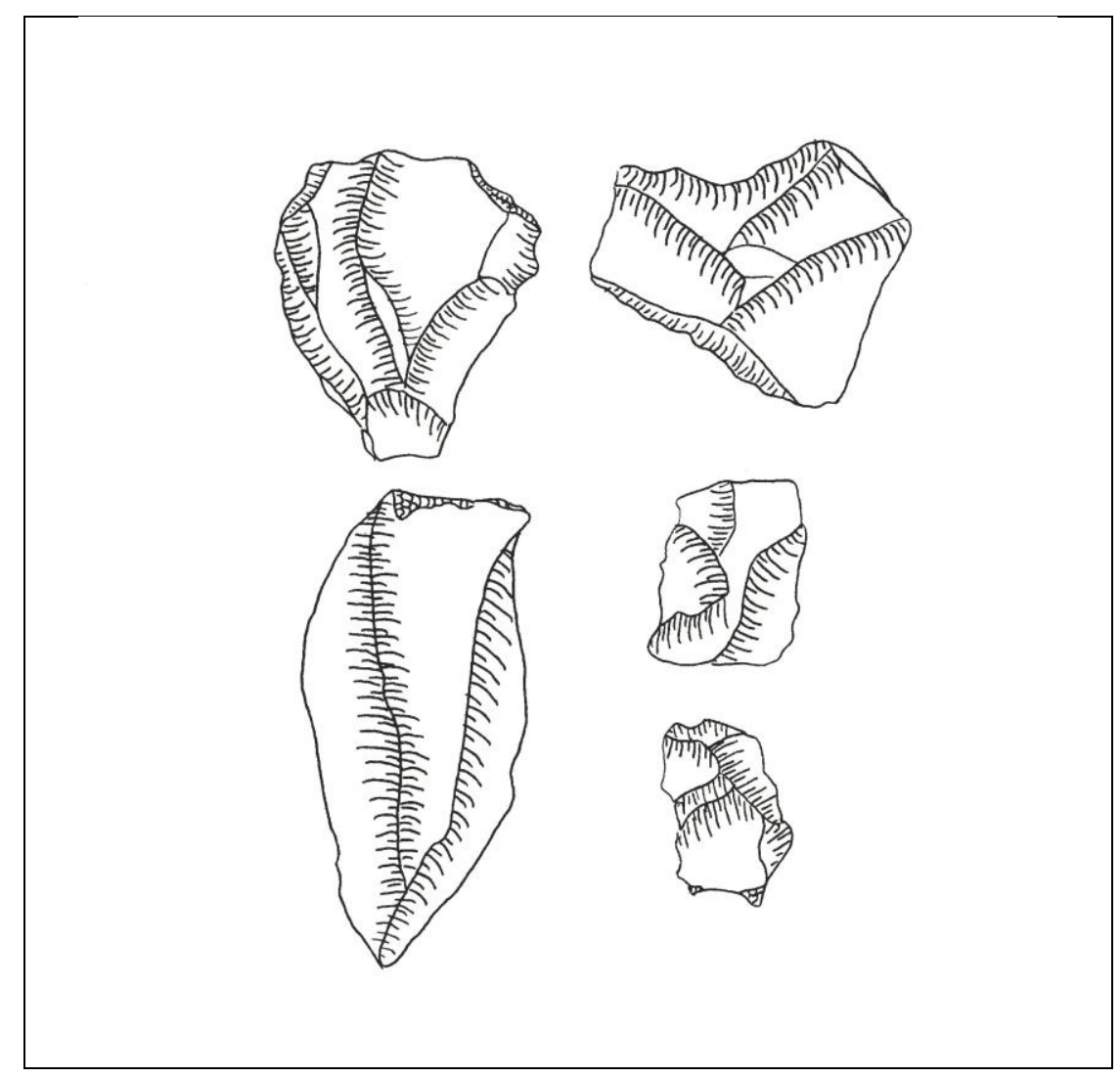

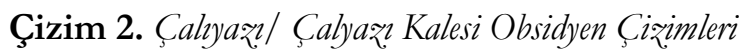

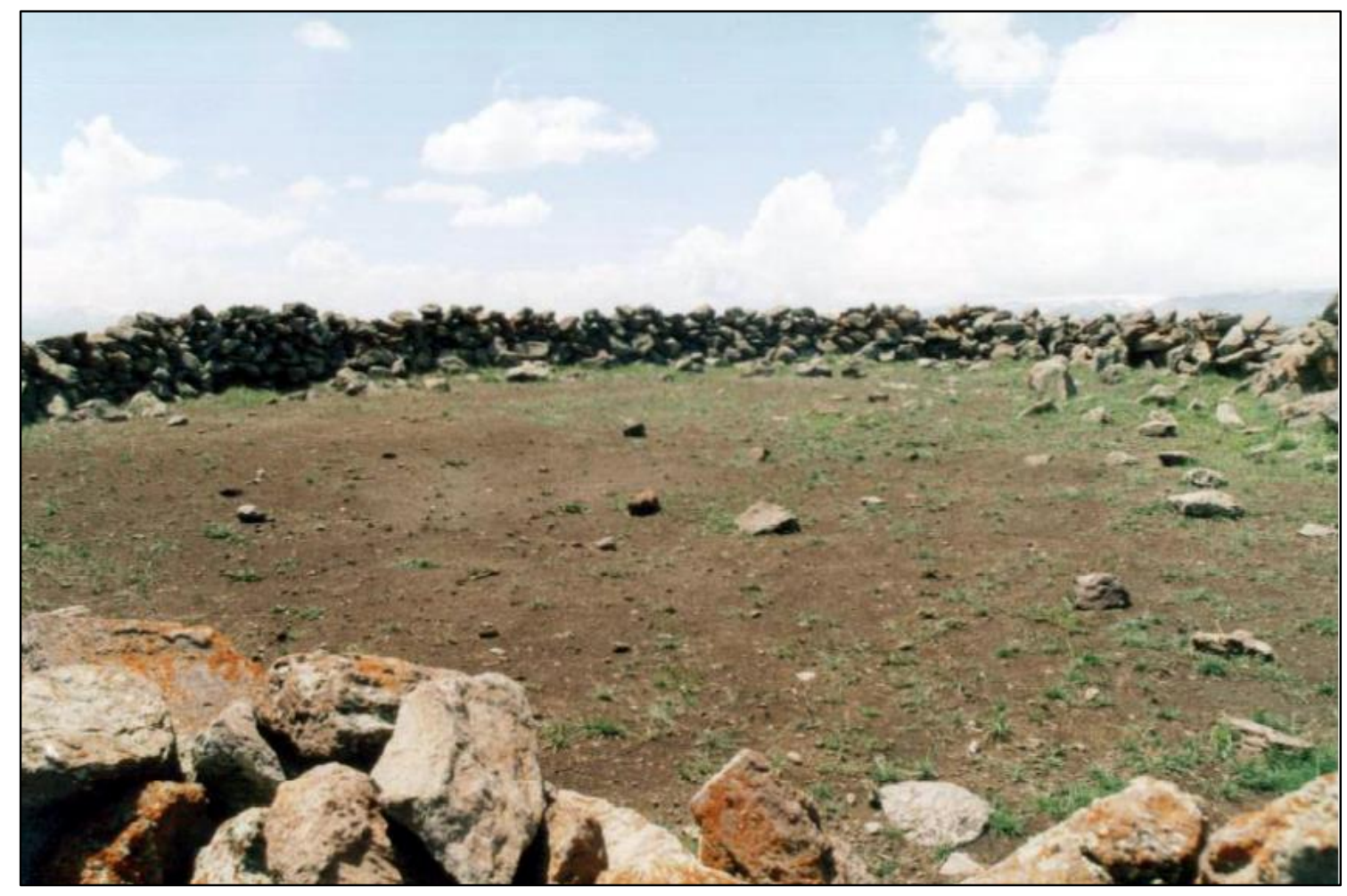

Foto 6. Kavusturan Kalesi 


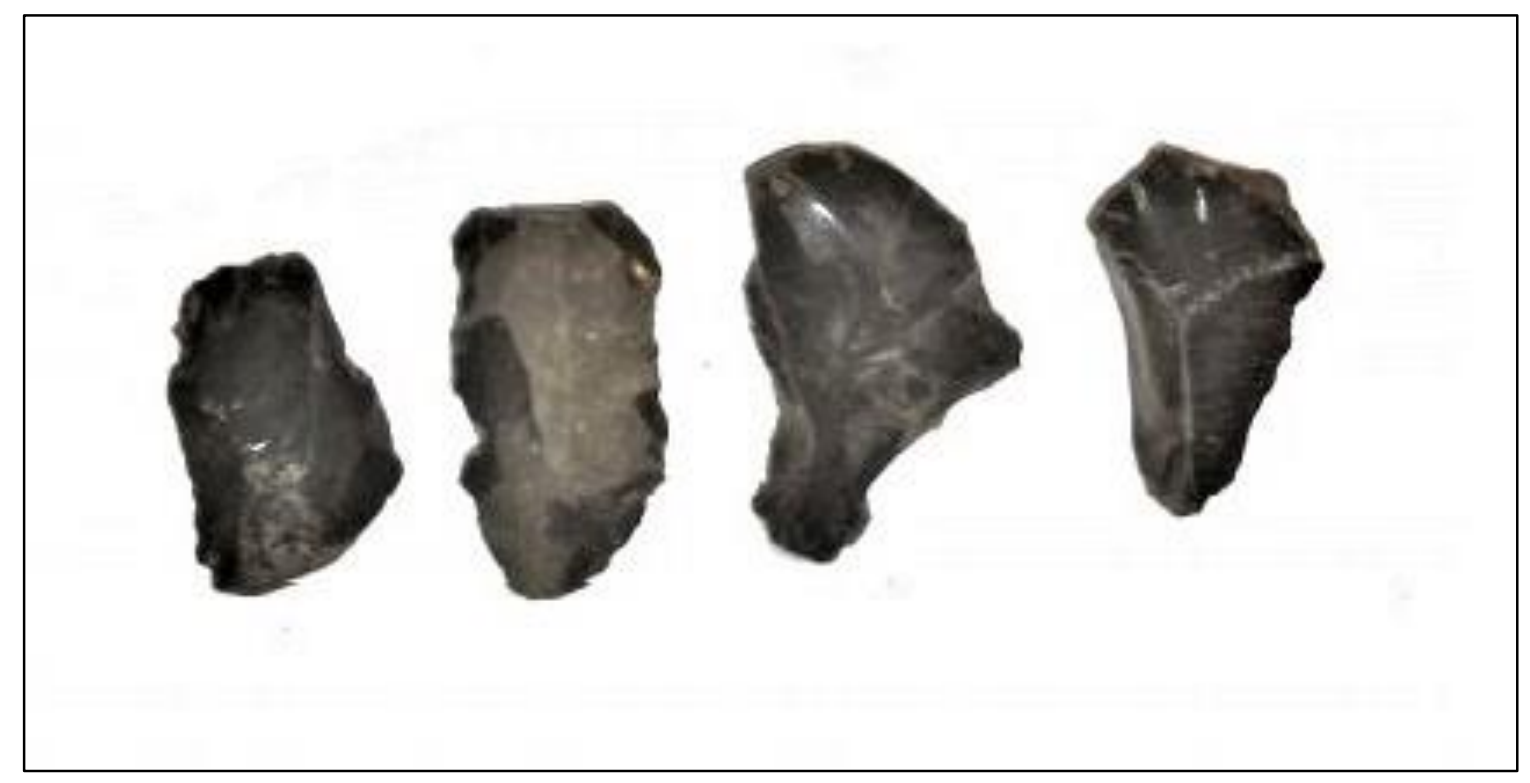

Foto 7. Kavusturan Kalesi Obsidyen Örnekleri
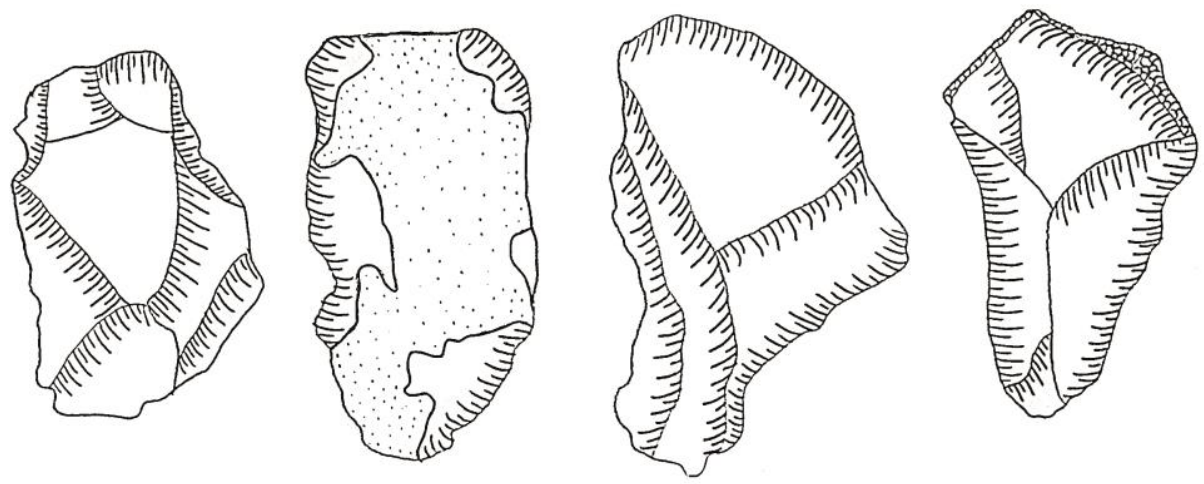

Çizim 3. Kavusturan Kalesi Obsidyen Örnekleri Cižimi 


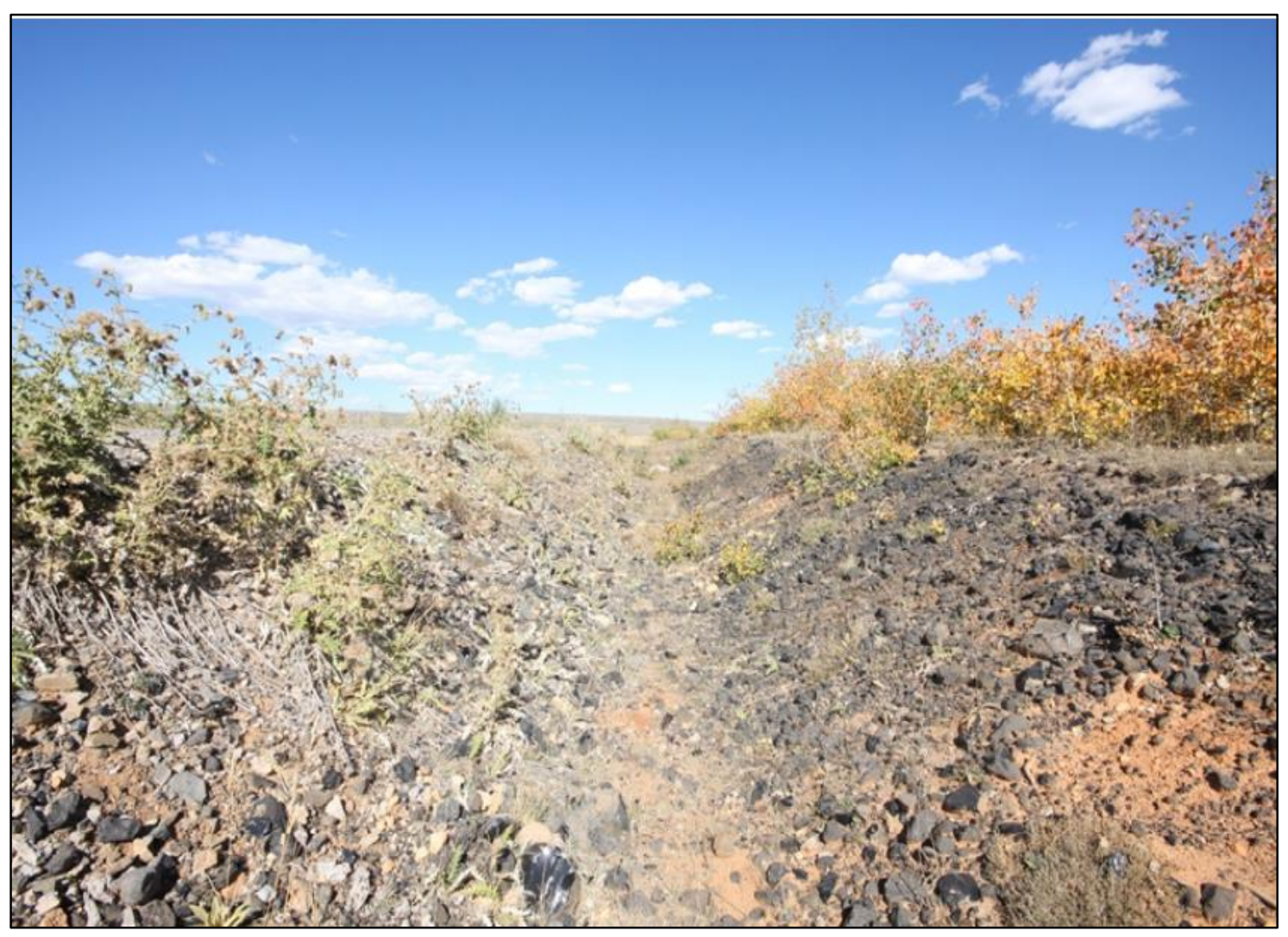

Foto 8. Kotandüzü Obsidyen Merkezi Genel Görünümü

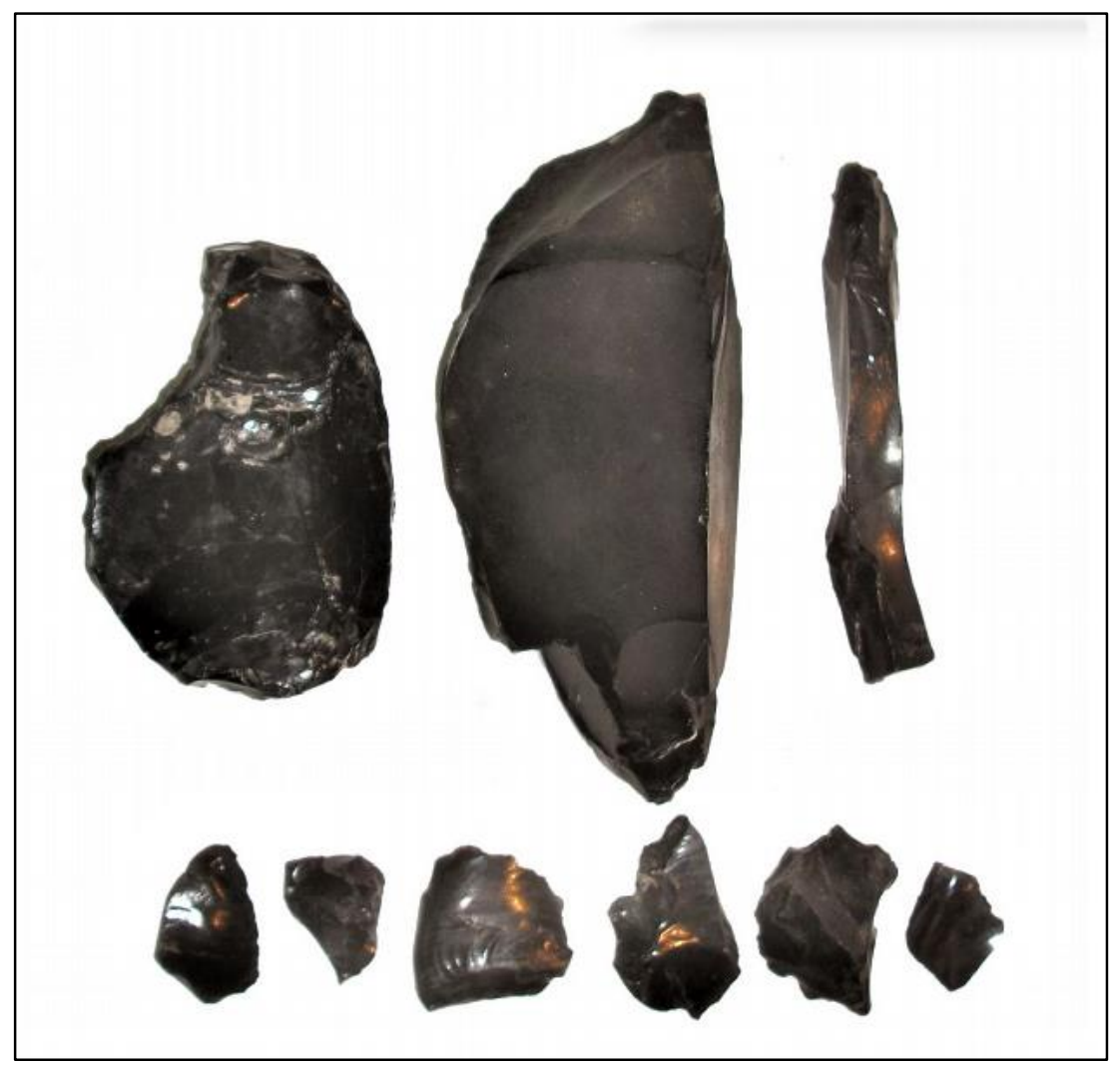

Foto 9. Kotandüzü Obsidyen Merkezi Obsidyen Örnekleri 


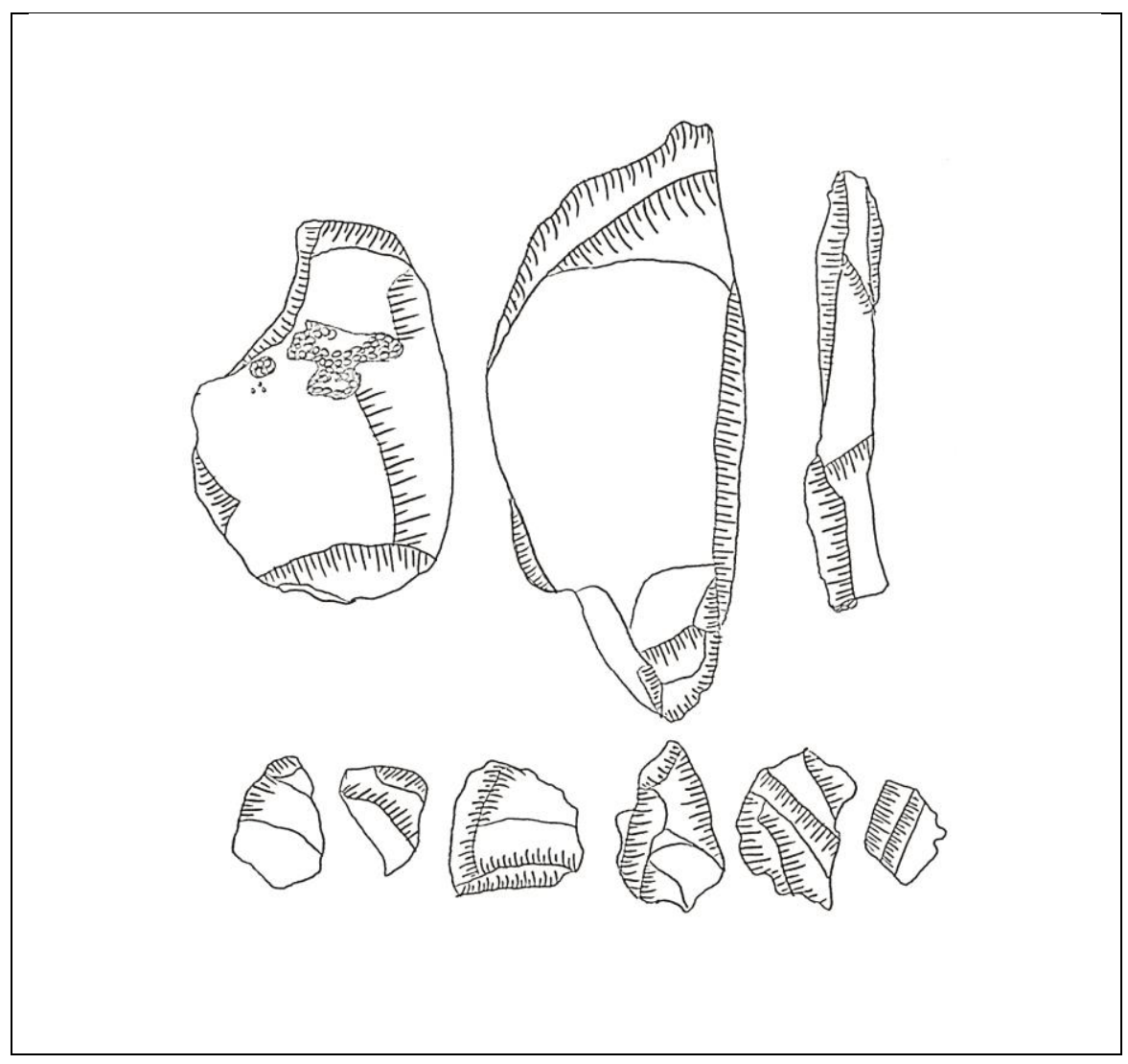

Çizim 4. Kotandüzü Obsidyen Merkezi Obsidyen Örnekleri Çizimi

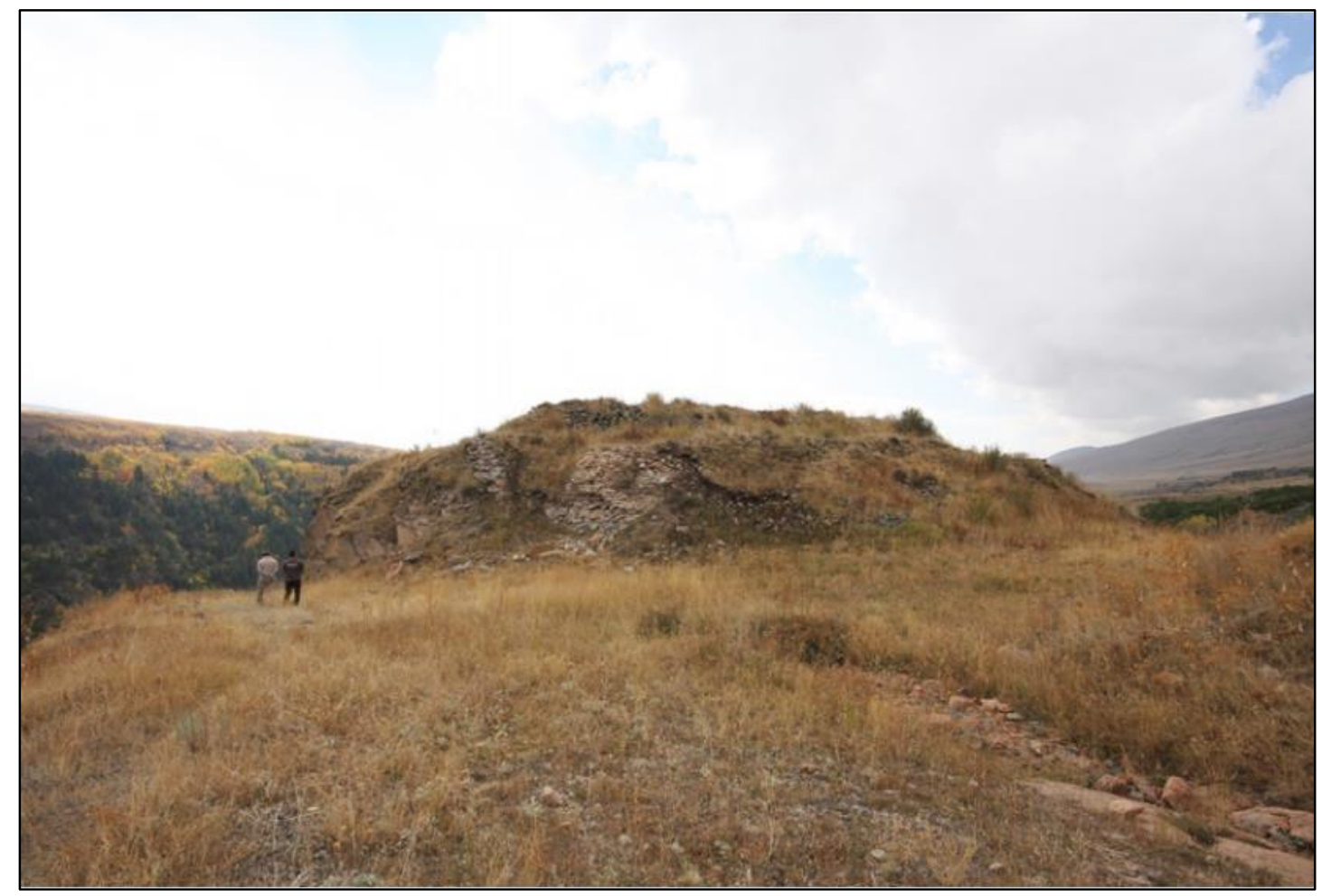

Foto 10. Pelitli Kalesi Genel Görünümü 


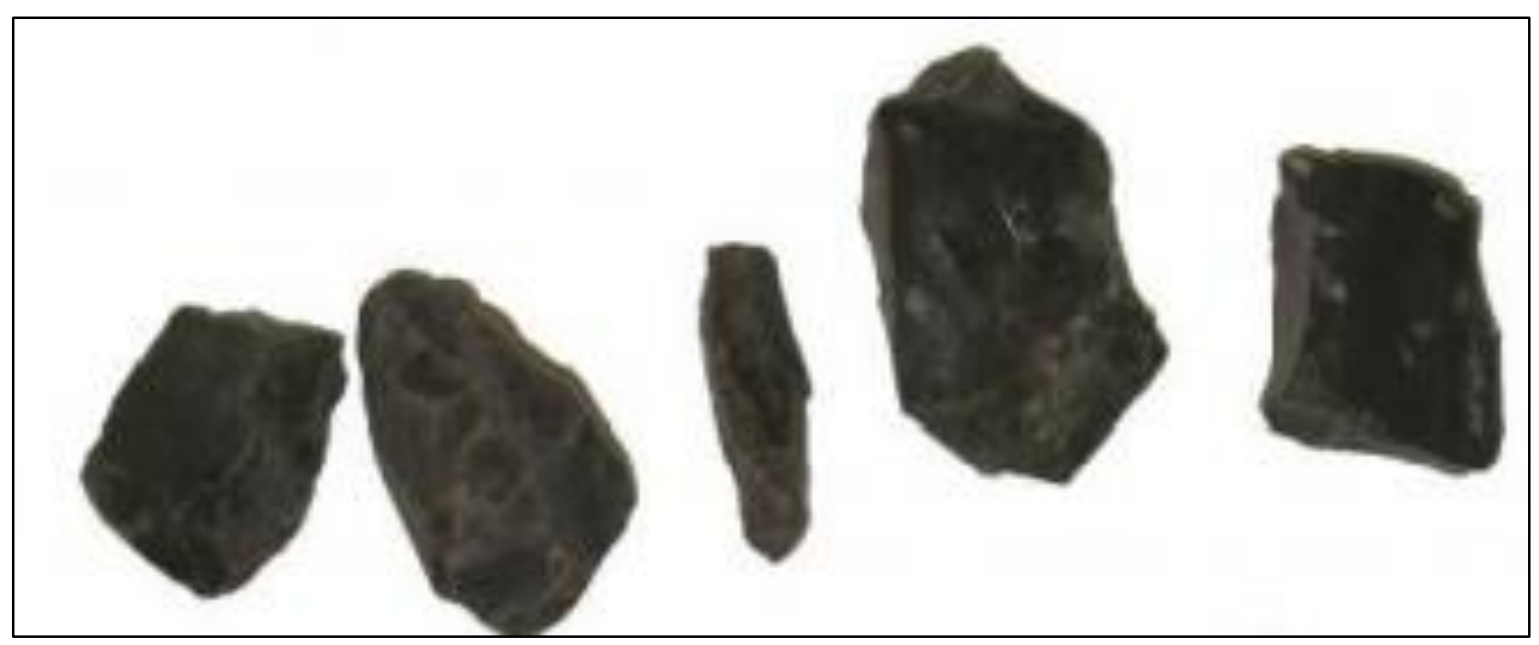

Foto 11. Pelitli Obsidyen Merkesi Obsidyen Örnekleri

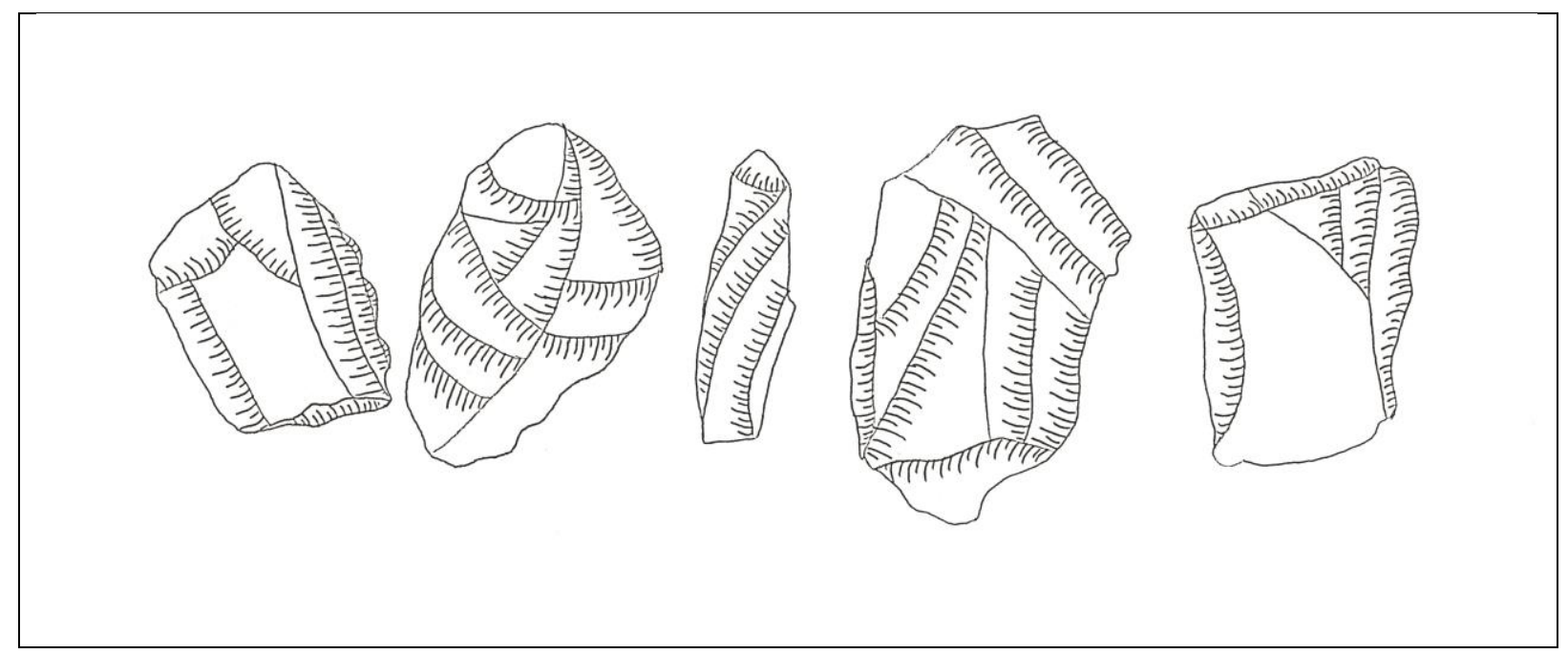

Çizim 5. Pelitli Obsidyen Merkesi Obsidyen Ömekleri Çiચ̨imi 
CEYLAN ve AKÇELİK

Yüzey Araştırmalar Işı̆̆ında Erzurum Pasinler İlçesinde Tespit Edilen Obsidyen Merkezleri ve Atölyeleri

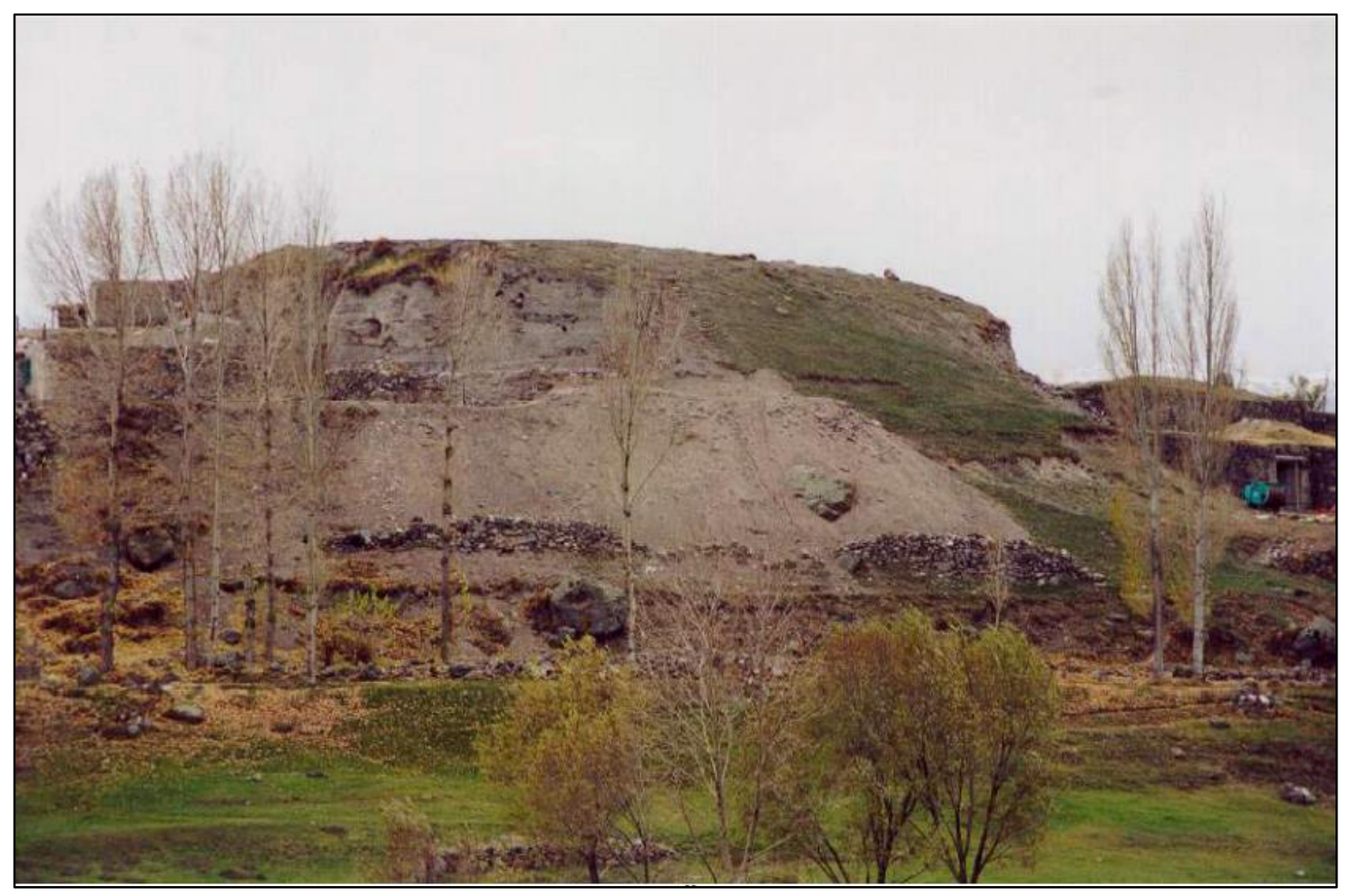

Foto 12. Sos Höyük Genel Görünümü

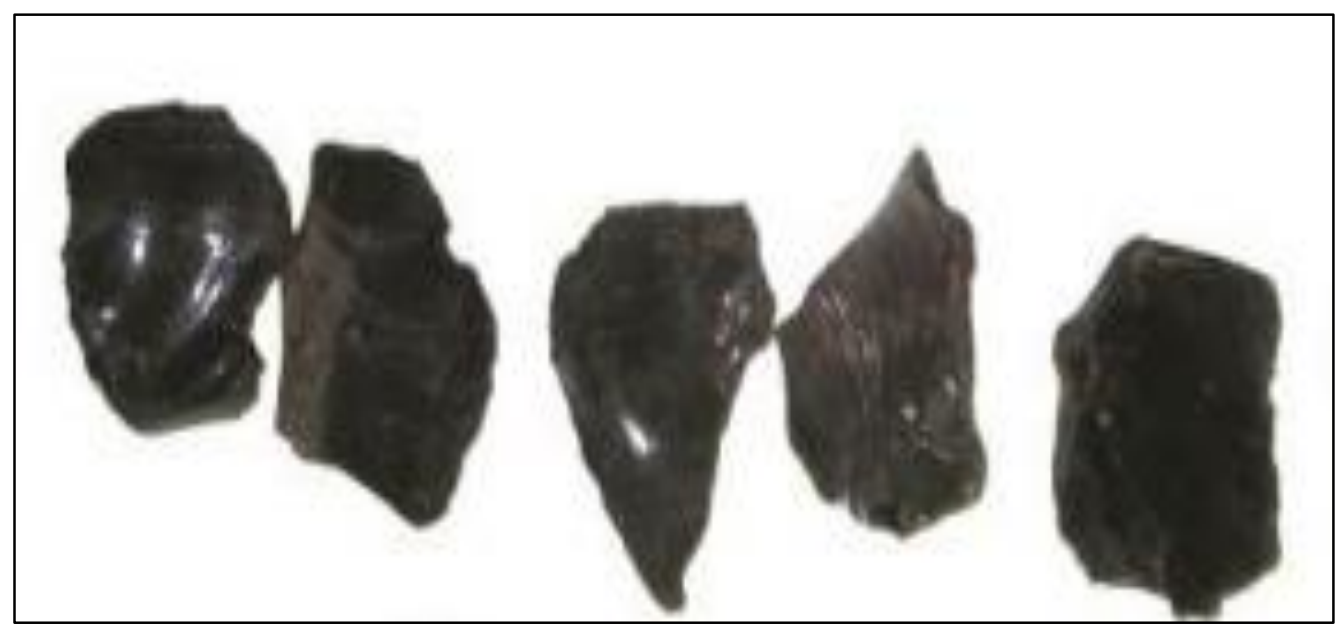

Foto 13. Sos Höyük Obsidyen Örnekleri 


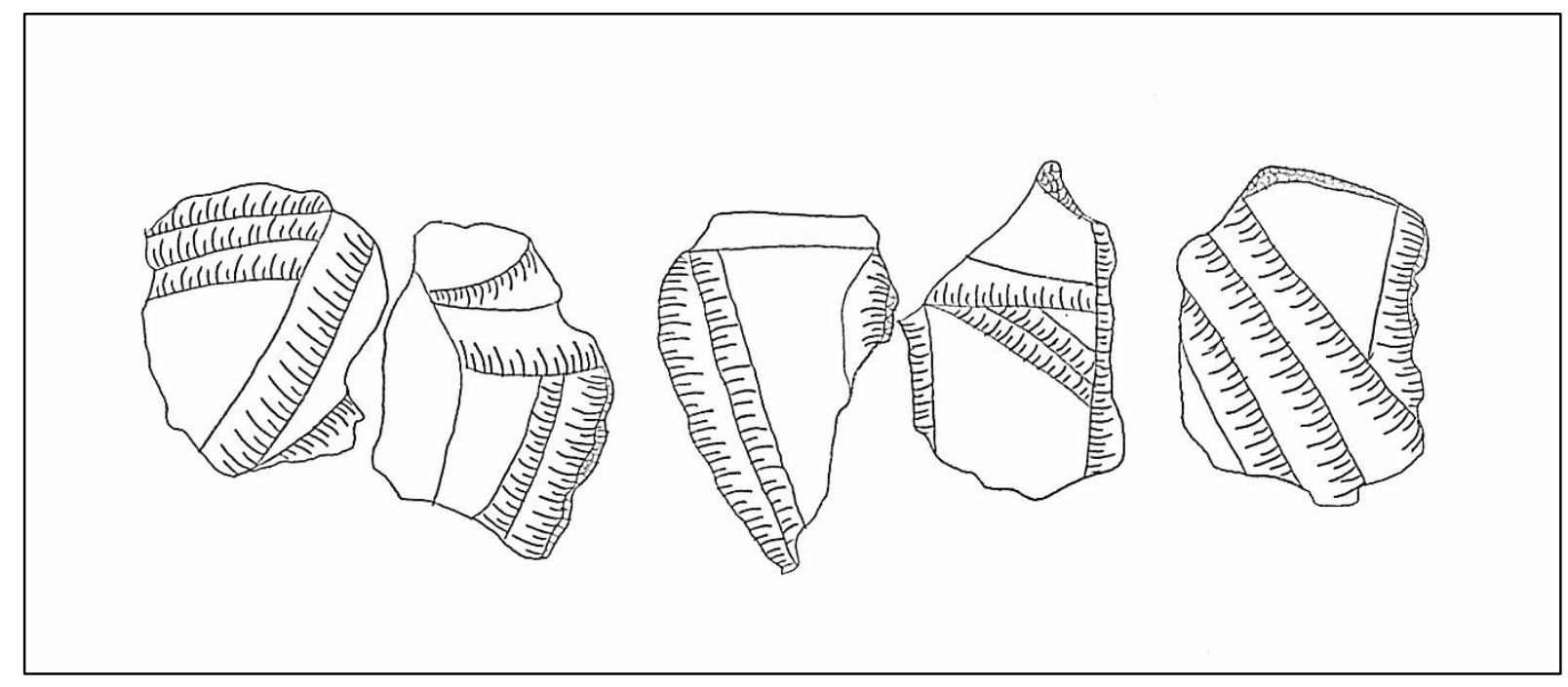

Çizim 6. Sos Höyük Obsidyen Ömekleri Ciəָ̧imi

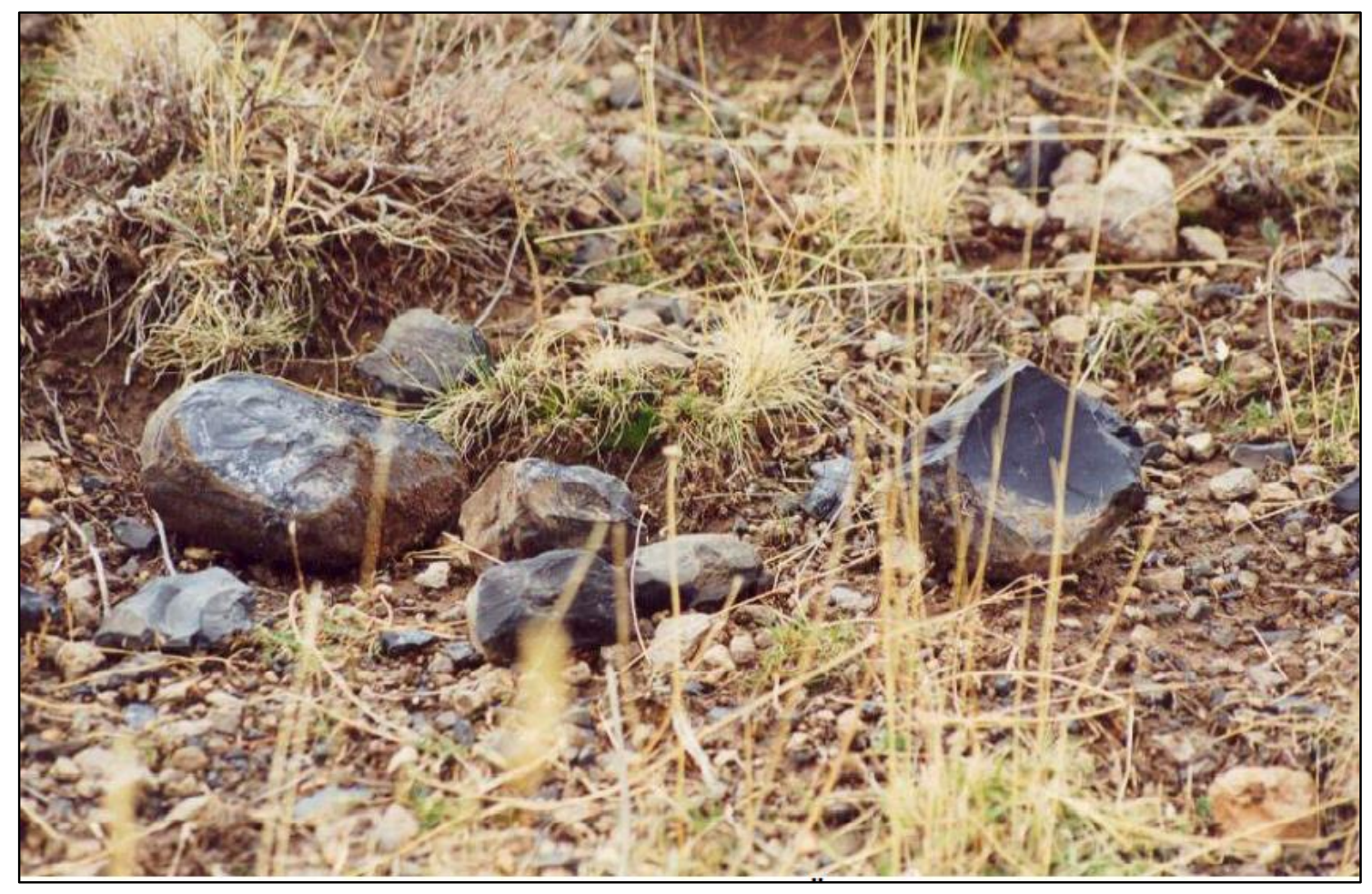

Foto 14. Timar Obsidyen Merkezi 


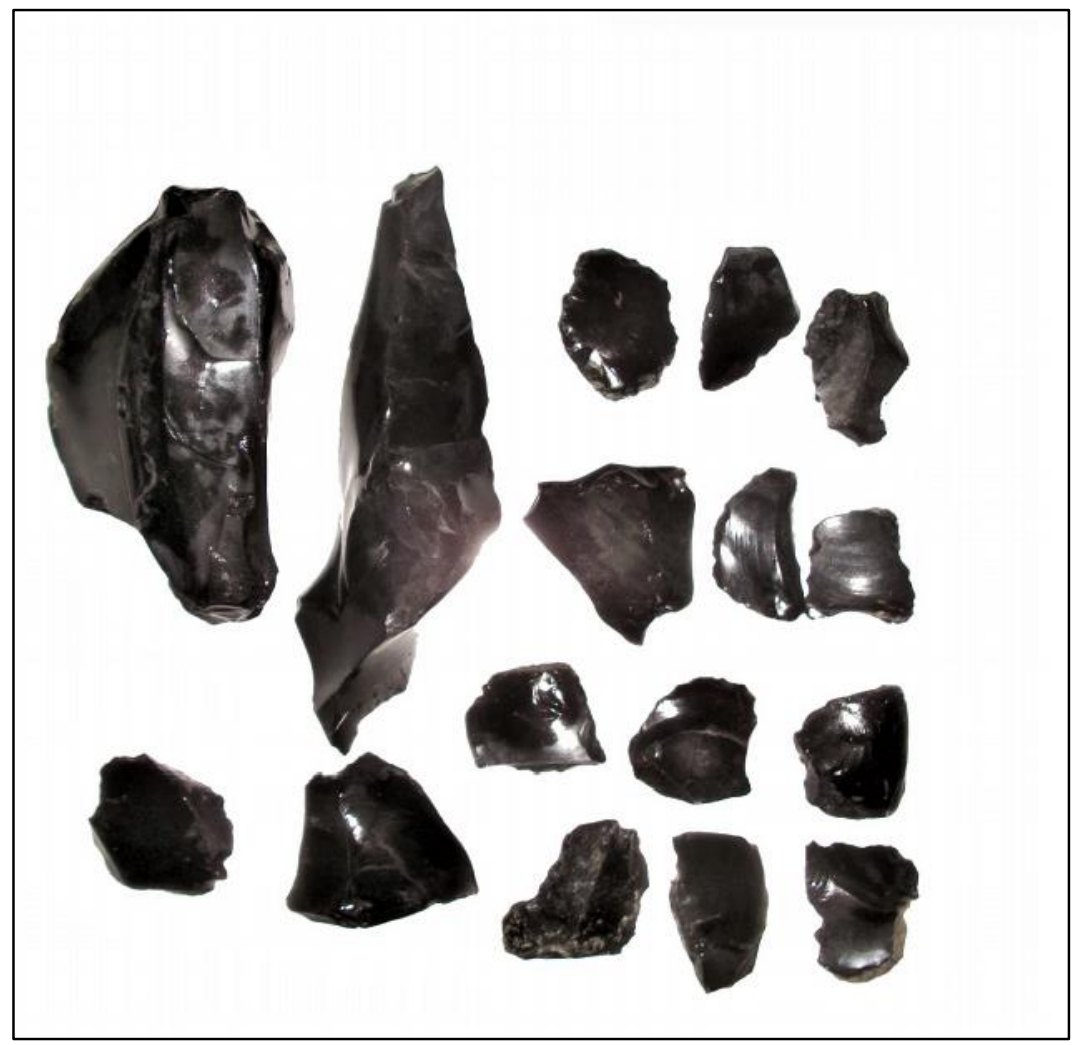

Foto 15. Timar Obsidyen Merkezi Obsidyen Örnekleri

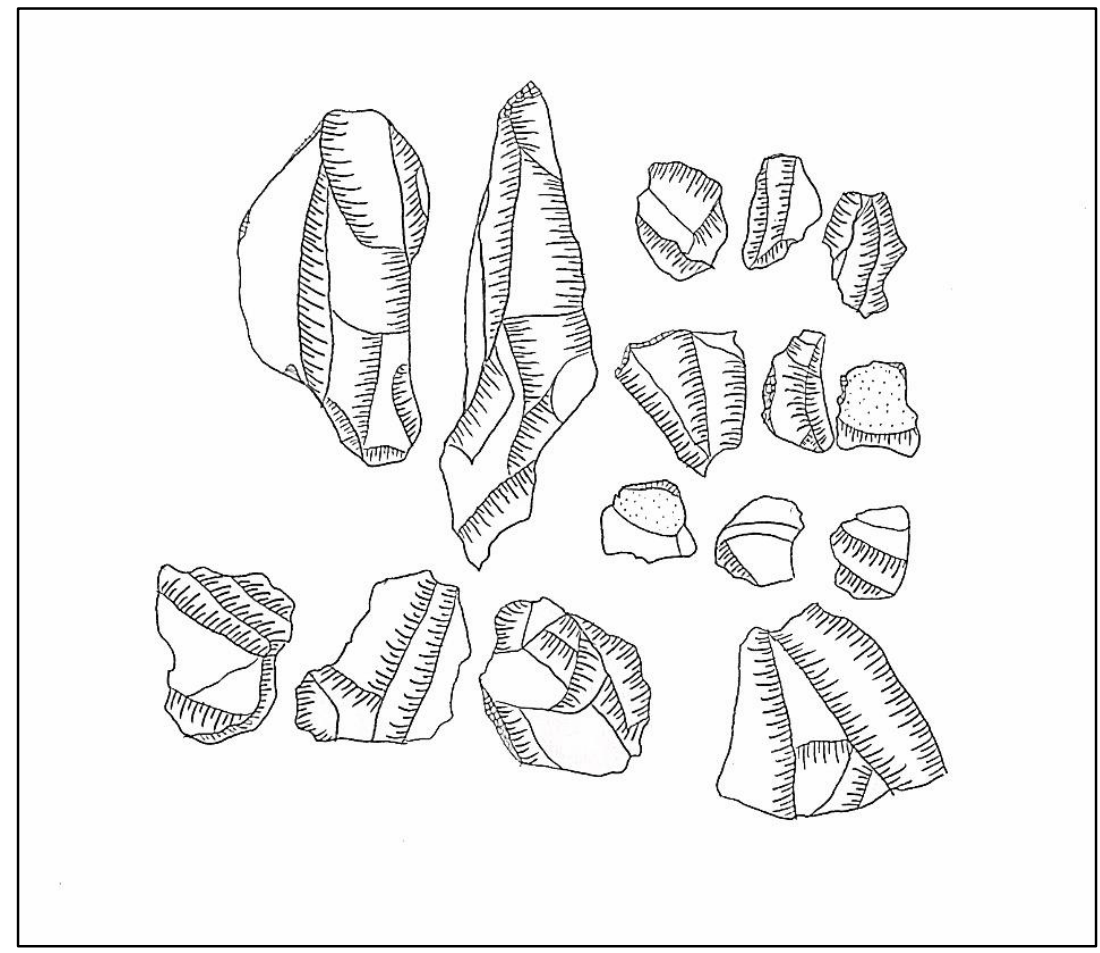

Çizim 7. Timar Obsidyen Merkę̧i Obsidyen Örnekleri Çizimi 